\title{
Aeg kui bessermani traditsioonilise maailmamudeli kategooria
}

\begin{abstract}
Jelena Popova
Teesid: Artikkel annab ülevaate bessermanide traditsioonilisest ajakäsitusest, mis on arenev ja pidevalt muutuv, sisemistele ja välistele mõjutustele alluv süsteem. Aeg maailmamudeli osana määrab looduslikud, pärimuskultuuri, majandustegevuse ja inimese elutsükli rütmid. Igal ööpäeva osal oli oma nimetus. Ohtlikud ja erilised olid kesköö ja keskpäev. Nädalapäevad jagunesid positiivseteks (kerged) ja negatiivseteks (rasked), mis võisid mõjutada ettevõetavate tööde õnnestumist. Aastaring on põhinenud sesoonsel arvestusel, mis mõjutas oluliselt kogu majandust, määrates külaühiskonna elu, kaasa arvatud perekondlikud ja olmelised tavad. Aega on kellade kasutuselevõtuni mõõdetud paljude käepäraste vahenditega. Oluline on olnud päikese ja kuu liikumise jälgimine. Bessermanid on ühitanud paljud vanad tähtpäevad, pühad ja surnute mälestamise kombe õigeusu kirikukalendriga.
\end{abstract}

Märksõnad: aasta, ajaarvestus, bessermanid, nädal, pärimus, rahvakalender, traditsioonilised pühad, tähtpäevad, õigeusk, ööpäev

Bessermanid (beser, beserman) on Venemaa põliseid väikerahvusi, kes elab kompaktselt Loode-Udmurtias. 2002. aasta rahvaloenduse andmetel on bessermane 3100. Enne seda arvestati bessermane eraldi rahvusena viimati 1926. aasta rahvaloendusel ( 10035 inimest Vjatka kubermangu Udmurdi autonoomses oblastis). Sealt kuni 2002. aastani arvati nad udmurtide hulka. Bessermanid on säilitanud etnonüümi, rahvusliku eneseteadvuse ning ainelise ja vaimse kultuuri eripära. Nad räägivad udmurdi keele bessermani murret. Levinud on ka vene ja tatari keel. Usutunnistuselt on nad peamiselt õigeusklikud (Škljajev 1997a, 1997b).

Praegusel asualal on kirjalikud allikad fikseerinud bessermanide olemasolu 16. sajandil ja 17. sajandi alguses, märkides, et nad elavad siin kõrvuti udmurtide, venelaste ja tatarlastega (Luppov 1931: 118-119). Uurijate oletusel ilmusid bessermanid Vjatka äärde 14. sajandi lõpus või 15. sajandi alguses pärast bulgaaride (bolgaaride) ja teiste Volga-Kaama rahvaste Kesk-Vol- 
gamaa ja Kaama ülemjooksu piirkonda rajatud Volga-Kaama-Bulgaaria feodaalriigi (10.-13. sajand) lagunemist, nende lõplik vormumine etnilise rühmana paigutatakse ajajärku pärast ümberasumist (Grišina \& Vladõkin 1982: 25-27). Bessermanide uurimise ajalugu käsitleb peamiselt etnogeneesi ja rahvuse varast ajalugu (üksikasjalikult vt Tepljašina 1970: 5-22; Popova 1997: 3-18, 2004: 4-12). Ajaloolased, etnograafid ja keeleteadlased on peamiselt püüdnud välja selgitada bessermani kultuuri türgi (bulgaari) ja soome-ugri (permi) komponente.

\section{Aeg ja maailmapilt}

Bessermanide traditsiooniline ajakäsitus on arenev ja pidevalt muutuv, sisemistele ja välistele mõjutustele alluv süsteem. Aeg maailmamudeli osana määrab looduslikud, pärimuskultuuri, majandustegevuse ja inimese elutsükli rütmid. Nüüdisaja bessermanid mõtlevad ajast peamiselt olmesfääris, säilitades siiski sakraalse konteksti. Aeg on üks põhikategooria ja mütopoeetilise maailmamudeli komponent, aeg ja ruum esindavad maailmakõiksuse kontekstis algkorda, mis korrastavad loomisel tekkiva kaose ja toovad esile sakraalsed aja parameetrid (Toporov 2000: 162).

Bessermanide kosmogoonilistest ettekujutustest puuduvad varased üleskirjutused, tänapäevased materjalid on üsna fragmentaarsed ega võimalda täiel määral taasluua kõiki kujutelmi, eriti müütilist maailma loomise aega, mil ilmusid kultuuriheerosed ja inimene. Müütiline aeg eelneb ajaloolisele ehk empiirilisele 'profaansele' ajale ja kujutab endast järgnevate sündmuste algpõhjust (Meletinski 2000: 252). Kui juttu on üsna kaugeid aegu puudutavatest sündmustest, kasutavad bessermanid tavaliselt määratlusi dun'n'e vorz'ekon dâr'ja1 'kui maailm sündis', dun'n'e vorz'ekemlâs' val'l'o 'enne maailma sündi', so sâče kemalas' val, ku muz'em no ejna val potemân 'see oli nii ammu, et isegi maa polnud veel sündinud'. Selliseid mõisteid kasutatakse, rõhutamaks nende sündmuste arhailisust, mille kohta inimmälu ei ole säilitanud ühtki konkreetset orientiiri (nt nälg, sõda, haigused).

Minevikusündmusi määratletakse tavaliselt väljendiga val'l'ona, mis tähendab 'väga vanad ja kauged ajad'. Mõiste hõlmab nii möödunud (sealhulgas müütilist) aega kui ka neljast-viiest inimpõlvest kaugemat minevikku, nii nimetatakse näiteks 80 -aastasi ja eakamaid vanureid. Sündmuste minevikust (mõnikord müütilisest ajast) tänapäevani ja tulevikku suunatud loetelud põhinevad üsna selgelt lineaarsel ajakäsitusel.

Maailma lõpust dun'n'e bâron ('maailma lõpp', sõnasõnalt 'maailma hukk'), mil katkeb ka aja kulg, on säilinud suhteliselt vähe fragmentaarseid teateid, 
mis osutavad piibli, suulise pärimuse ja massimeedia mõjutustele. Varasemate vanadelt inimestelt kuuldud teadete järgi hukkub maailm tules või tule läbi või kõik põleb ära või hukkub vee läbi. Erinevalt hilisaegsetest teadetest, mille järgi maailma lõpp saabub 2000. aastal või sajandivahetuse paiku, ei ole varasemates tekstides juttu mingitest tähtaegadest ega ajavahemikest. Maailma lõppu määratakse kui aja kulgemise lõppu: Milline aeg? Mitte midagi ei saa olema.

Minevikusündmused peegeldavad kujutlust aja lineaarsest kulgemisest ja on seotud perepärimusega (sugupuu, esivanemad, vanemad ja vanavanemad). Siia juurde on arvatud ka ajalooline ja koha- ehk toponüümiline pärimus, mis sisaldab andmeid asustuse tekkimisest, esimestest asukatest ja sakraalsete objektide (pühad hiied, kalmistud, jõed, allikad) ilmumisest. Asunduse elanikud arvestavad aega küla tekkemomendist, lülitades sinna jutustused asukate eellastest ja ammustest sündmustest. Pärimuse kohaselt on loodusobjektidele allikatele, jõgedele, tähtsatele kohtadele - andnud nimed küla asutanud esivanemad. Sõnaga, teatava keskkonna kultuurilise omandamise aega ja ajalooliste sündmuste kulgu arvestatakse just alates asunduse rajamise hetkest. Paljud suguvõsad on sel viisil seotud esmaasukatega, st nad on seotud kauge minevikuga. Sugulussuhted avalduvad kui sootsiumi liikmete side ajalooliste muistendite aegadest tänapäevani. Tänapäeva inimesed omakorda on ühendusniit minevikust järglaste kaudu tulevastesse põlvedesse.

Ettekujutused ajast ja aastast on kandunud edasi kujutlustesse hauatagusest maailmast. Oletati, et seal, nagu maapealses eluski, vahetuvad aastaajad, esivanemad teevad ühele või teisele aastaajale vastavaid talutöid, neil on tarvis sooje talverõivaid jmt.

\section{Ööpäev}

Ööpäevaring (uj-nunal 'öö-päev') kajastus rikkalikus olmeliste keeldude süsteemis. Päev (nunal) hõlmas rahvalike ettekujutuste järgi ajavahemikku päikesetõusust loojanguni, öö ( $u j$ ) loojangust päevatõusuni. Igal ööpäeva osal oli oma nimetus. Nii koosnes päev mitmest osast: čuk 'hommik', obed pal 'lõunaaeg' või nunal šor 'keskpäev', obed ber 'pärastlõuna', žăt pal 'õhtupoolik', žăt 'õhtu'. Hommikut kui öölt valgele päevale ülemineku aega (koiduaega) nimetati čuk pal 'hommikuaeg', päeva kandumist öösse (loojanguaega) uj pal 'õhtuaeg/õhtu'. Kesköö (ujšor) oli öö keskpaiga nimetus, koidueelset aega kutsuti uj ('öö’). Öö- ja päevatundide pikkus sõltus aastaajast. Igal ööpäeva osal oli oma semantiline tähendus. 
Ajavahemikuga keskööst koidueelse ajani algas nähtavasti uus ajalõik $u j$ nunal, mis vastab tänapäeva ööpäevale. Selle ajalise parameetriga seonduvad uute tööde alustamist puudutavad arusaamad ja kombed, mitmed rahvaravitsemispraktika normid ja rida (põllu)majandustegevusi. Rahvalike ettekujutuste kohaselt päev "pöördus" pärast keskpäeva ja võimust võttis juba uus ööpäev. Võib oletada, et ettekujutus seniidi (keskpäeva) ületanud päikesest on seotud väljendiga, et ta pöördus uude päeva. Sellega seostuvad ilmselt ka keeld pesta õigeusu pühade või rahvakalendri tähtpäevade eelsel pärastlõunal pesu ning teha muid töömahukaid ja tähtsaid majapidamistöid, sest pärast keskpäeva on päev kaldunud juba uude, palju tähenduslikumasse ööpäeva. Mõningaid tööde, pühadekommete ja rõivastusega seotud keeldusid pehmendati mõnevõrra (eriti hooajaliste põllutööde puhul), nii et need ei kehtinud pärastlõunase aja kohta, seda isegi pühade ajal. Sellist normist kõrvalekaldumist õigustati vajadusega lõpetada tööd kindlaks tähtajaks või sellega, et päev sai otsa ja aeg kaldus juba järgmisse, tavalisse ööpäeva.

Ööpäeva osadega seotud keelud ja käsud määrasid käitumist, majapidamistöid, kombeid ja rituaalseid tegevusi. Suure sakraalse koormusega olid päikeseloojang ja päikesetõus, keskpäev ja kesköö, ööpäeva esimene ja teine pool, hommik ja õhtu. Hommikut ja päeva esimest osa peeti uue töö alustamisel ja ostude sooritamisel heaks ajaks, neid seoti positiivsuse ja tulemuslikkusega. Enne lõunat püüti näiteks soetada karja, käia kosjas, alustada uue maja ehitust ja asuda pikale teele. Oletati, et kariloomade ost ja kosjaskäik on edukad, soetatud kaup aga "kohaneb" majapidamises, kui tehing on sooritatud kasvava päikese ajal (šundâ budon vâle - päikesetõusu ajal, päeva esimesel poolel).

Karja sõidetakse ostma hommikul. Muidu tabab kahi ja ebaõnn. Ei sigine. Lehm ei too vasikat, hobune varssa. Mõned seda ei järgi. Sõidavad mü̈̈ma suvalisel ajal, aga endale ostma - ainult hommikul enne lõunat. Pärast lõunat ei tohi (AVM < Balezino raj, Gordino k - Ž.Z.I. (1999)).

Kui sõidetakse majapidamisse karja ostma, et seda pidada, mitte lihaks ostma, tuleb minna enne lõunat. Pärast lõunat läheb päev kahjumisse (AVM < Jukamenskoje raj, Filimonovo k - K.N.A. (2000)).

Karja sõidetakse ostma enne lõunat, öeldakse, et päev muutub. Pärast lõunat hulgub palju šaitane. Nii rääkisid rahvas ja vanad inimesed (AVM < Jukamenskoje raj, Šamardani k - K.R.M. (2000)).

Need ettekujutused on seotud uskumusega, et ainult tõusva päikese ajal soetatu on edukas, kari annab palju juurdekasvu, ohvrid võetakse vastu. Nii püsisid igapäevaelus ettekujutused ööpäeva sakraalse tähendusega positiivsetest ja negatiivsetest osadest. 
Ööpäeva osad seostusid puhta ja ebapuhta, soodsa ja ohtliku ajaga. Näiteks jaotati ööpäev kaheks pooleks - päev (nunal) ja öö (uj) olid kvaliteedilt erinevad. Ööd peeti kurjade vaimude ja haiguste aktiivsuse perioodiks, mille tipphetk saabus keskööl. Pärast loojangut ei koristatud ruume ega jäetud õue lasterõivaid, oletades, et neisse asuvad haigusvaimud ja šaitan (AVM < Jukamenskoje raj, Žuvami k - M.I.K. (1995)). Sellega on seletatav ka keeld tulla tagasi koju ja astuda tuppa südaööl. Reegel laieneb nii kaugelt tulijatele kui ka oma küla piirest koju naasjatele:

Aega kutsutakse nevrama, kui see on kaldunud üle kesköö. Keskööl ei tohi tarre astuda, šaitan tuleb koos sinuga sisse (AVM < Jukamenskoje raj, Filimonovo k - K.N.A. (2000)).

Nevramat peeti umbes tund aega [öösel - J.P.], umbes südaöö paiku. Kui ôhtul kuhugi minna, tuleb seda teha enne keskööd. Pärast keskööd ja enne ühte juba ära liigu. Ja tagasi on vaja tulla enne keskööd. [---] Vaat kaks-kolm loeti olevat hea aeg. Leiti, et aeg on hommikupoolne. Öeldi, et on olemas lud babam [metshaldjas - J.P.]. Vaat, räägitakse, et enne keskööd käib ta siia-sinna (AVM < Jukamenskoje raj, Šamardani k - S.M.B. (2000)).

Selline päeva ja öö, valguse ja pimeduse vastandamine on Nina Braginskaja arvates elementaarne semantiline mudel, millega on seotud peaaegu kogu kalender ja ööpäevaring, kus põimuvad solaarsed-ööpäevased ja aastaajalised-agraarsed tsüklid, mis ühendavad üldise tähenduse alusel hea ja halva alge võitluse (Braginskaja 2000: 613).

Pärimustekstide põhjal on ajal pärast keskpäeva (õhtul ja ööl), samuti põhjaja läänekaarel täiesti teised karakteristikud kui lõunal, idal ja päeva esimesel poolel. Ajaliselt olid reglementeeritud ka majapidamistööd. Näiteks püüti mitte minna pärast loojangut vett tooma (AVM < Jukamenskoje raj, Filimonovo k S.K.M. (2000)), keelatud oli ka tööde alustamine (AVM < Balezino raj, Gordino k - Ž.A.P. (1999)), karja tapmine (AVM < Balezino raj, Gordino k - Ž.Z.I. (1999)), võlgu andmine, nugade teritamine ning toiduainete ja asjade viimine võõrasse majapidamisse (AVM < Jukamenskoje raj, Tõlõsi k - B.T.S. (2000)). Pärast loojangut võlgu andmise keeld on seotud ettekujutusega, et see toob kaasa vilja äpardumise, loomade kehva kaaluiibe ja kariloomade haigestumise (AVM < Jukamenskoje raj, Tõlõsi k - J.M.S. (2000)). Loojangujärgse aja negatiivne tähendus ilmneb eredalt haiguste ravimisega seotud tavandites. Kui näiteks haiguse põhjust seletati sellega, et inimene leidis selle halval ajal ja ohtlikus kohas, viidi ohvriand (riideribad, vill, mündid või toiduained) hämaruses. Aeg ja ruum esinevad samas kontekstis ja nendega seotud reeglite rikkumine on haiguse põhjuseks. Vaid ohverdamine üleminekuajal (koidi- 
kul ja loojangul) tagab ja taastab aja ja ruumi tabu rikkunud inimese soodsa ja esialgse seisundi.

Päike on tähtis kronoloogiline ja ruumiline orientiir. Märkimist väärib, et aega ja ruumi, ööpäeva osi, päikese asendit horisondil ja valguse varjundeid tähistatakse ühesuguselt. Näiteks nimetatakse ida, hommikut ja päikesetõusu šundâ sâlton / šundâd'užan 'külg, kust päike tõuseb', šundâ žučekon pal 'külg, kust päike kerkib'; päeva lõppu, loojangut ja läänt - šundô puks'on dəิr 'aeg, kui päike loojub', šundâpuks'on pal 'päikeseloojangu külg'; ööd ja põhja - ujšor 'kesköö', ujšor pal 'kesköö külg', ujpal ‘öökülg'. Valguse ja päeva osi võidi tähistada ka sarnaselt: põhi - uj ‘ọö', lõuna - nunal 'päev', ida - čuk 'hommik', lääs - žàt 'õhtu'.

Ida ja kagu, nagu ka päeva esimene pool kandsid positiivset märgistust, aga põhi ja loe negatiivset. Näiteks kalendripühadel ennustustamise ning riituste ajal ja enne külvi idast või lõunast kuuldud hääled olid hea viljasaagi ja heaolu ended, põhjast ja läänest kuuldud nälja-aasta ja nekrutipõlve ennustajad (Tepljašina 1970: 278).

Üsna kindlalt on tänapäevastes ettekujutustes ajast ja ruumist juurdunud põhjakaare seostamine kesköö ja ööga. Ööpäeva seda osa puudutav kombestik oli seotud surnute austamise, nõiduse mahavõtmise ja kurjade vaimude väljaajamisega. Kui näiteks lapse unetust seletati esivanemate vihaga, ohverdati neile pärast loojangut ja põhja suunas (Popova 1998: 70); mälestuspüha laud kaeti ning viimased surnute mälestamised koos lehma (või hobuse) pea ja jalgade kadunukesele ohverdamisega korraldati samuti õhtuhämaruse saabudes. Keskööl või täieliku pimeduse saabudes viisid eakad inimesed looma pea ja jalad surnuaia suunas (Bijanova 1946: 15), põhja või loode poole. Arvati, et ainult siis võetakse ohver vastu. Järelikult muutus hämaruse saabudes piir siin- ja teispoolse maailma vahel tinglikuks. Teatud kalendriperioodidel peeti teispoolse maailma sissetungi ülimalt võimalikuks: kolmapäeva öö vastu suurt neljapäeva on udmurtidel ja bessermanidel tuntud kui kulem'jos poton $u j$ 'surnute väljatulemise öö'.

Endiselt mitmekesine ja püsiv on rahvaravitsemise praktikas ettekujutus haigustest, mis "haarasid" inimese, kes viibis nende elupaigas ebakohasel hetkel - halval ajal orod dôr / urod dôr või valel ajal nevrama. Märkigem, et sellised maastikuobjektid on kohalikele väga hästi teada. Nende hulka kuuluvad orud, allikad, teeristid, tänavalõpud ja kohad, millega on kohapärimuse järgi seotud kellegi äkksurm, samuti enneaegselt sündinud või ristimata surnud vastsündinute matmispaigad. Keeldude rikkumine võib põhjustada ränga psüühikahäire, nõrkuse, nahahaiguse või mädapaised, mis jutustajate meelest ilmnevad kõige sagedamini päeva teisel poolel ja pimeduse saabumisel. 
Kõige tähenduslikumate ajapiiride hulka kuulub keskpäev. Kui päike on seniidis, ei lubata supelda, minna põllule ega metsa, asuda pikale teele. Usuti, et sel ajal on tõenäoline kohata hiiehaldjat čaššakuzjo / ludkuzjo ja põlluhaldjat mežakuzjo, kes käivad oma valdusi vaatamas - nendega kohtumine võis põhjustada raske ja pikaajalise haiguse. Sellega on seotud ka keeld puhata keskpäeval metsateel, pühade hiite või mingis mõttes tähenduslike puude läheduses. Arvati, et need kuuluvad hiie- või põlluhaldjale, kes seal elavad ja puhkavad. Selle uskumusteringiga seotud endeid ja keelde võib kohata ka tänapäeva tekstides:

Kàž-màž öeldakse, kui satud valel ajal halba kohta või teed seal midagi. Külviajal puhkasime lõuna ajal kuuse juures, aga seal ei tohi puhata. Ma tõusin ja kohe hakkas selg valutama. Ka muul ajal on seal ohtlik. Ohtlik aeg on keskpäeval ja öösel (AVM < Jukamenskoje raj, Žuvami k N.Z.S. (1993)).

Nagu näidetest selgub, võib ööpäevase puhke- ja tööajakorralduse rikkumine kahjustada looduse tasakaalu ja inimese tervist.

Hommikuhämarusel (čuk akšan) ehk päikese tõusmise ajal ja õhtuhämarusel (Žăt akšan) ehk ajal päikese loojumisest pimeduse saabumiseni oli ööpäevas oluline koht, neid peeti piiriks öö ja päeva vahel ja nad olid semantiliselt koormatud. Näiteks õhtuhämu saabudes tuli pikali visata ja oodata pimeduse saabumist; ei tohtinud õhtust süüa ega tööd alustada. Viimase ajani püsinud uskumuste kohaselt võis nende keeldude rikkumine tuua kaasa kauakestva närvija psüühikahäire või ootamatu vigastuse. Piiriajal, nagu ka keskpäeval, muutusid ohtlikuks sakraalse tähendusega alad:

Hämaruses on seal [orus - J. P.] kuulda rinnalapse nuttu. Akšan - see on paha aeg. Kui valel ajal sellisesse kohta satud, siis kuuled, aga pärast jääd põdema. Akšani ajal tuleb istuda kodus (AVM < Jukamenskoje raj, Tõlõsi k - Š.F.J. (1995)).

Hämaral ajal väljast sisse tulles pidi puudutama ahju, et vabaneda haigustest, mis inimene võis endaga majja kaasa tuua. Samalaadseid pimedusega seotud uskumusi võis kohata ka põhjaudmurtide seas. Näiteks tuli hämaruses tööd alustades või tuld süüdates ahju juures käsi soojendada (Pervuhhin 1888: 57). Bessermanide keelde väliskeskkonnaga kokkupuutumise, uute tööde alustamise ja pidustuste kohta võib seletada ennekõike kurjade vaimude ja haiguste aktiivsusega vaatlusalusel ajavahemikul. Uskumuste kohaselt läksid isegi sel ajal lausutud needused alati täide. Samasuguseid uskumusi on täheldatud ka mitme piirkonna udmurtidel (Vereštšagin 1886: 27; Vladõkin 1994: 223; Minnijahmetova 2000: 89). 


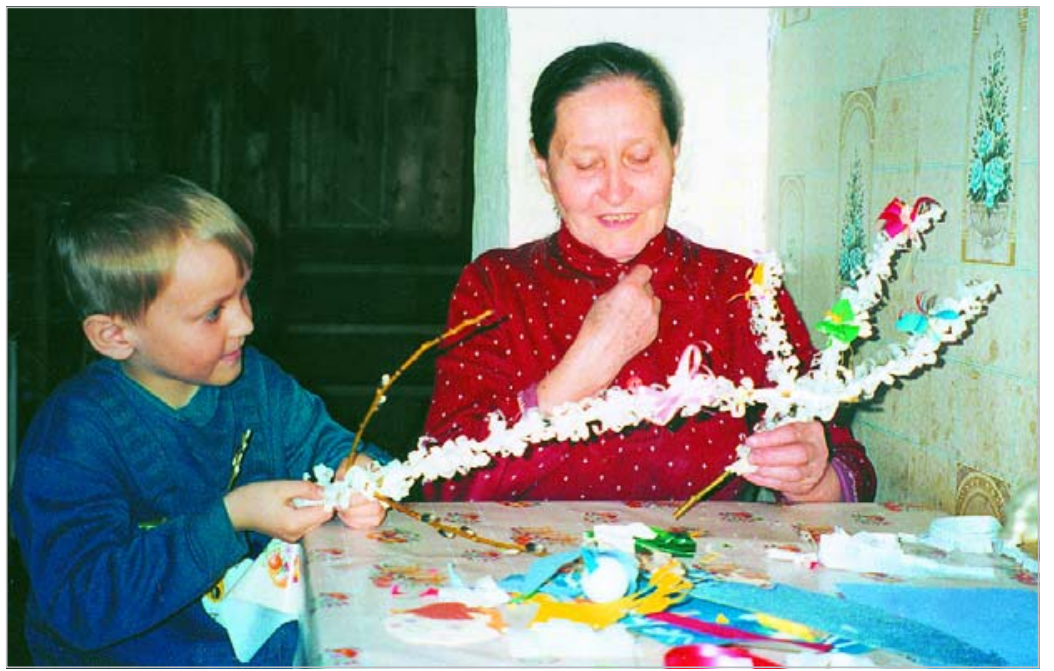

Foto 1. Urbadega okste kaunistamine urbepäevaks (palmipuudepühaks) Jukamenskoje rajooni Žuvami külas 2000. aastal. Jelena Popova foto.

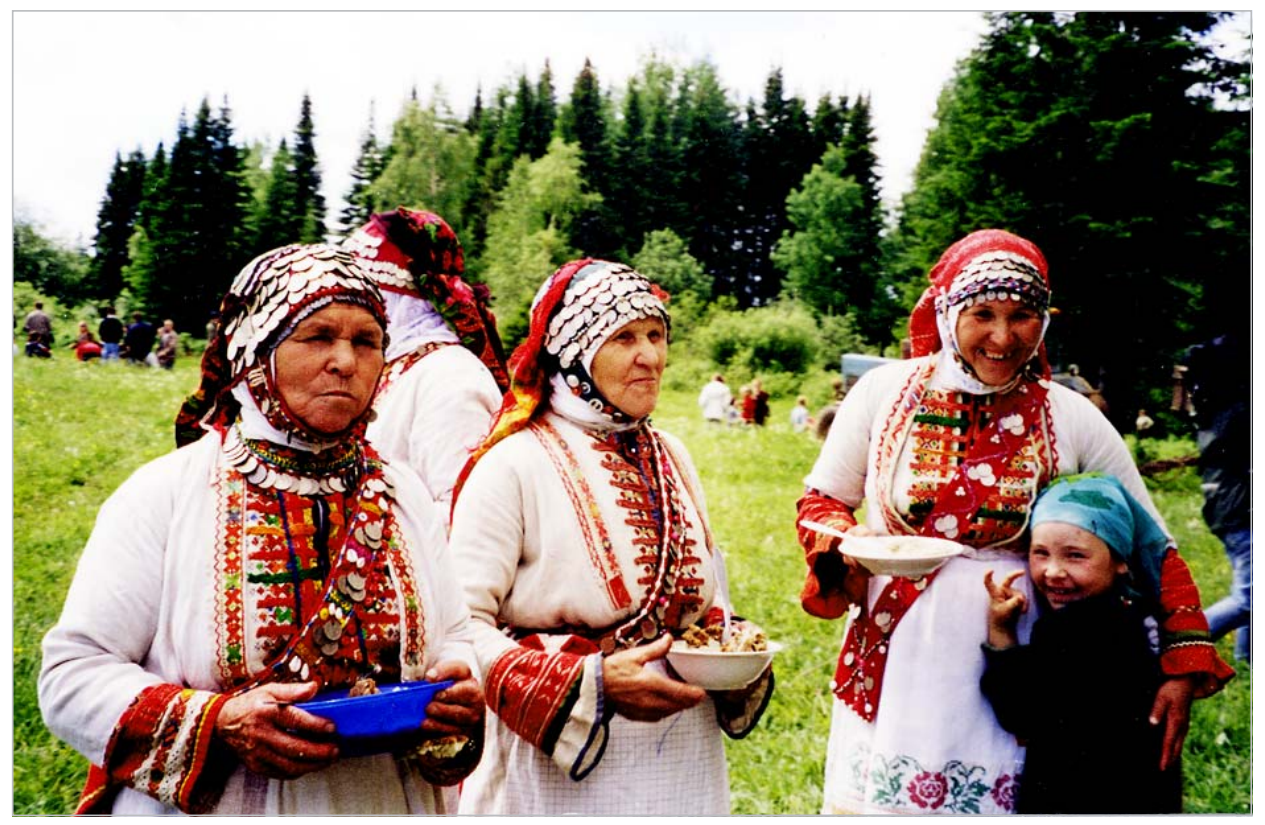

Foto 2. Žuvami küla bessermani naised 2004. aasta suvisel kurbani ühispalvel Jari rajooni Vortsa külas. Jelena Popova foto. 
Õhtu- ja hommikuhämarus sisaldasid erineva kvaliteediga aegu. Oluliseks peeti päikeseketta horisondile ilmumise hetke: hoolega kuulates võivat kuulda erilist pragisevat häält. Udmurtidel valitses uskumus, et horisondile lõikudes teeb päike pragisevat häält nagu tuline pird, kuid seda võib kuulda vaid tugev ja tuline ratsu (Vereštšagin 1889: 140). Koitu ja päeva esimest poolt peeti positiivseks. Näiteks sel ajal allikast toodud veel arvati olevat raviomadused. Päikesetõusu ajal korraldati ka ohverdamisi.

Päeva ja öö, päikese ja kuu kordumine sümboliseerib maailma stabiilsust ja harmooniat, vastandudes kaosele. Igasuguseid muudatusi koheldi kui kataklüsmi või õnnetusekuulutajaid. Ööpäeva tsüklilisuse (koit ja agu, hommik ja õhtu) kohta annavad huvitavat teavet loitsud. Näiteks algavad paljud tekstid:

Ö̈̈ tuli tagasi, päev tuli tagasi, päike tuli tagasi. Kuu tuli tagasi. Ja see [endine seisund - J. P.] tulgu tagasi (uj bertem, nunal bertem, šundâ bertem. tolez' bertem. ta no med bertoz) (AVM < Jukamenskoje raj, Ježovo k - A.T.I. (1996)).

Rõhutagem veel kord, et ööpäeva osade kordumine ja tsüklilisus on käsitletav kui maailma püsimise ja stabiilsuse tagatis.

\section{Nädal}

Nüüdisaja sõnavaras ei ole säilinud nädalapäevade traditsioonilisi nimetusi, neid ei ole mainitud ka varastes allikates. Kõige püsivamaks on osutunud sakraalselt tähenduslike päevadega seotud terminoloogia. Need on kolmapäev arnja šor 'nädala keskpaik' ehk viro / vironunal 'verepäev' ja laupäev - pominka nunal 'mälestamise päev'.

Nädal - arnja - koosnes meie kasutada olevate üsna hiliste materjalide põhjal seitsmest ööpäevast. Nädalapäevad jagunesid positiivseteks (kerged) ja negatiivseteks (rasked). Sellest lähtuvalt määrati kindlaks tähtsate majapidamistööde, perekondlike kombetalituste, karja väljalaskmise ja külvi ajad. Uskumuste kohaselt võis päeva positiivne või negatiivne iseloom mõjutada ettevõetavate tööde õnnestumist. Sellepärast on täiesti mõistetav nende uskumuste püsimine ka praeguse maaelanikkonna seas:

Karja pü̈̈takse välja lasta reedel. Öeldakse, et teisipäeval ei tee vareski pesa. Teisipäeval ei lubata karja välja lasta (AVM < Balezino raj, Gordino k - Ž.S.I. (1999)). 
Esmaspäeval ei tohi karja välja ajada, nii öeldi. Eriliselt peeti silmas. See on kõlvatu päev. Ka teisipäeva peeti samasuguseks. Öeldi, et teisipäeval ei tee lind ka pesa. Ja veel on kindlad kuupäevad mais ja juunis. Neil päevadel ei tohi karja välja ajada. Loomad jäävad haigeks (AVM < Glazovi raj, Korotai k - P.M.A. (1999)).

Kolmapäeval ja laupäeval ei sõidetud ka kosja. Mõnevõrra edukamate päevade hulka kuulusid teisipäev ja neljapäev (Jukamenskoje rajooni Žuvami ja Ježevo küla). Arvati, et kolmapäev on ohvritoomise päev, laupäev surnute mälestamise päev. Pühapäeval - arn'a nunal 'nädalane päev' - ei tehtud lõunani tööd, seda peeti suureks päevaks (zek nunal), tööd võis teha alles pärast keskpäeva, nagu ka pühade ajal. Näiteks pühapäeval ja pühade ajal viljalõikust ei alustatud, lubatud olid üksnes talgud (AVM 2000, 2003). Kardeti, et keelu rikkumisel süütab välk vilja või toob see kaela õnnetuse ja halva ilma.

Tatari-bessermani segakülades võtsid bessermanid omaks tatarlaste erilise suhtumise reedesse. Austusest moslemitest naabrite kalendri vastu püüdsid bessermanidki tatarlaste eeskujul reedel mitte pesu pesta ega koristada (AVM < Balezino raj, Gordino k (1999)). Suhtumise nädalapäevadesse määrasid mitmed asjaolud:

Esmaspäev ja kolmapäev on halvad päevad. Rä̈̈gitakse ka tarehaldjast (korkakuzjo), ôuehaldjast (gidâkuzjo). Neljapäeval ja pühapäeval pandi neile [ohvriande - J.P.]. Meil ei peetud reedet halvaks päevaks. Reede oli hea päev. Kodus ja väljaspool midagi erilist ei korraldatud. Aga tatarlastel loetakse reedet kõige suuremaks päevaks. See on tatarlaste päev. Sellisel päeval ei teinud nad mitte midagi (AVM < Jukamenskoje raj, Turtšino k - Z.J.G. (2000)).

Erilist suhtumist reedesse bessermanide nüüdiskultuuris võib seletada pikaajalise kokkupuutega moslemiusuliste tatarlastega ja islami mõju säilimisega (Popova 1998: 178-179). Reedet kui moslemi pühakodade ja kalmistute külastamise päeva on täheldatud Tšepetski tatarlaste juures.

Päev omandas positiivse tähenduse siis, kui samal ajal peeti laata või oli kirikupüha. Positiivsete ja negatiivsete nädalapäevade puhul tuleb silmas pidada, et eri piirkondades on mõningasi erinevusi. Näiteks Junda ja Gordino küla bessermanidel on rasked päevad esmaspäev, teisipäev ja reede, kerged laupäev ja pühapäev. Lekmas, Lemas ja Ubõtis elavad bessermanid nimetavad sageli raskeks päevaks esmaspäeva ja kolmapäeva, kerged on neil neljapäev, reede ja pühapäev. 
Suhtumine nädalapäevadesse on osutunud sedavõrd püsivaks, et võimaldab määratleda etnilist ümbruskonda ja isegi selle piirkonna etnilisi protsesse. Näiteks Tšeptsa paremkaldal Alam-Sludkas ja Ust-Põšketsis, mis veel 20. sajandi esimese poole andmetel oli bessermanide ja udmurtide asuala, on olulise bessermane udmurtidest eristava joonena märgitud bessermanide suhtumist neljapäeva ja reedesse. Erinevalt naabritest põhjaudmurtidest, kes korraldasid nii perekondlikke kui ka ühiseid kalendaarseid surnute mälestamise päevi laupäeviti, alustasid bessermanid vastavaid ettevalmistusi juba neljapäeval ja korraldasid need reedel, aga kalmistule mindi ikka laupäeval. Neljapäeval valmistati tainast kakuleiva küpsetamiseks ja veristati ohvriloom, reedel aga kaeti kodus laud mälestussöömaajaks. Nendega samades asundustes elavad põhjaudmurdid omakorda veristasid ohvriloomi reedel, laupäeval aga korraldasid mälestuspüha söömaaja ja käisid kalmistul:

Udmurdid tähistasid mälestuspäeva laupäeval, aga bessermanid neljapäeval. Meie peame ka neljapäeval. Bessermanid pidasid siin seda neljapäeval. Siin korraldavad vaid üksikud mälestamisi laupäeval. Kõik veristavad lamba neljapäeval [---] Küpsetame kakuleiba ja korpi. Mälestame bessermani kombel (AVM < Glazovi raj, Ust-Põšketsi k - S.L.F. (1977)).

Sama traditsiooni järgitakse mainitud asundustes ka tänapäeval, ennekõike bessermani juurtega peredes. 20. sajandi teisel poolel pidasid Alam-Sludka ja UstPõšketsi bessermanid end juba udmurtideks, kuid mäletasid kirjeldatud kommet ja on seda järginud viimase ajani (AVM < Glazovi raj, Alam-Sludka ja Ust-Põšketsi k (1997, 2000)). Komme pidada neljapäeva pühapäeva kõrval pidupäevana püsis Junda ja Gordino kandis 20. sajandi keskpaigani (Bijanova 1946: 2).

Toodud näited tõendavad, et pisikeste, kuid kompaktselt paiknevate etniliste rühmade hinnangutes nädalapäevadele võib esineda väikesi, kuid olulisi erinevusi. Iseloomustades udmurtide suhtumist nädalapäevadesse märgib Tatjana Vladõkina, et rasketeks loeti kõik paaritud, aga kergeteks paarispäevad (Vladõkina 1998: 277-278). Samas näiteks Kaama-tagused udmurdid pidasid headeks päevadeks esmaspäeva, neljapäeva ja pühapäeva, halbadeks ehk rasketeks teisipäeva, kolmapäeva, reedet ja laupäeva (Minnijahmetova 2000: 94).

Analüüsides slaavi kalendri nädalapäevi, väitis Svetlana Tolstaja, et heade ja halbade päevade hindamise aluseks on rahva seas palju kriteeriume, mille alusel on tavaliselt koostatud universaalsed binaarsed opositsioonid nagu paaris - paaritu, mees - naine, esimene - viimane jne (Tolstaja 1987: 168). Viimastel aastatel on bessermanid arvestanud kergeid ja raskeid päevi rahvaravitsemises, mõnikord ka karja väljalaskmisel. 


\section{Aasta}

Ettekujutus ajast eeldas kogu põllumajandustööde tsüklit hõlmava kronoloogilise ajavahemiku - aasta (ar) - mõtestamist ja süstematiseerimist. Võib oletada, et aastaring põhines sesoonsel arvestusel: tulâs 'kevad', gužem 'suvi', siz'âl 'sügis' ja tol 'talv'. Aastaaegade piirid olid välitööde materjalide põhjal üsna tinglikud ja määrati ühe või teise talutöö alguse või lõpu, fenoloogiliste vaatluste või ilmamuutuse alusel.

Põllumajandusaastas oli kaks olulist perioodi: kevadsuvine ja sügistalvine poolaasta. Esimene oli seotud külvi ja põllukultuuride eest hoolitsemise, karja laskmisega suvekarjamaadele ja heinatöödega, teine aga viljalõikuse, karja lautaajamise, puude tegemise ning naistel kanepi ja lina töötlemisega.

Kalendritähtpäevadel ja -pühadel oli kummalgi poolaastal oma spetsiifika. Näiteks sisaldas kevadsuvine tsükkel palveid jumalustele, põlde ja metsa kaitsvatele haldjatele, esivanematelt paluti õnnistust eelseisvaks vilja-aastaks, stabiilsust ja küllust ning tervist. Aasta teise osa kombestiku, mis hõlmas viljalõikusele järgnenud hilissügist, täitsid tänuohvrid abi eest talutöödel ja aasta õnnestumise puhul. Kevadet ja suve peeti rituaalseks tegevuseks kõige sobivamaks ajaks, siis pöörduti uinuva või ärkava maailma poole (Lvova \& Oktjabrskaja \& Sagalajev \& Usmanova 1988: 47).

Aastaaegade vahetumine mõjutas oluliselt kogu majandust, mis omakorda määras külaühiskonna elu, kaasa arvatud perekondlikud ja olmelised tavad. Kevadtsükkel algas 20. sajandi rahvakalendris tavaliselt kannatusnädala kombestikuga, mis annab tunnistust rahvakalendri mugandumisest õigeusukalendriga. Rahvajutud ja paljude kommete analüüs lubavad oletada, et seda aega peeti uue maaviljelusaasta alguseks. Kevadtsükli kombestikus on valdavad produktiivse iseloomuga tegevused, mis märgivad uue majandus- ja elutsükli algust. Semantiliselt olulisima ajamärgina tuleb esile tõsta suurt neljapäeva, eriti kannatusnädala kolmapäeva ööd vastu neljapäeva. Suure neljapäeva hommikuga on seotud rida tavasid, mis on suunatud töö edukusele, viljakuse suurendamisele ja karja juurdekasvule, komme süüdata uus tuli ja tuua uut vett.

Mõistesse suvi kuulus aeg pärast suvisteid (kolmainujumala püha, nelipüha), suvises ohvripühast kurbani ( $k$ b̂rban) ühispalvest ${ }^{2}$ kuni eelijapäevani (20. juuli / 2. august). Suve keskpaika kutsuti gerber (sõnasõnalt 'aeg pärast kündi'), mis langes kokku suvise pööripäevaga.

Meil peeti gerberit suve keskpaigaks. Pärast seda liigub kõik sügise poole. Enne kui hakati heina tegema, oodati ära gerberi saabumine. Pärast 
gerberit enam ei niideta. Rohi läheb karedaks (AVM < Jukamenskoje raj, Šamardani k - B.V.N. (2000)).

Sügis algas pärast eelijapäeva ja kestab suurmaarjapäevani (pokrov, õigeusu kiriku neitsi Maarja kaitse ja eestpalve püha, 1./14. oktoober). Pärast eelijapäeva ei söödud enam suvemarju, ei ujutud ega tehtud vihtu. Nii olid keelatud mitte üksnes suvised toidud, vaid ka lõppenud aastaajaga seotud tööd. Arvati, et keelu rikkumine võib kaasa tuua haiguse või kliimamuutuse. Kos-

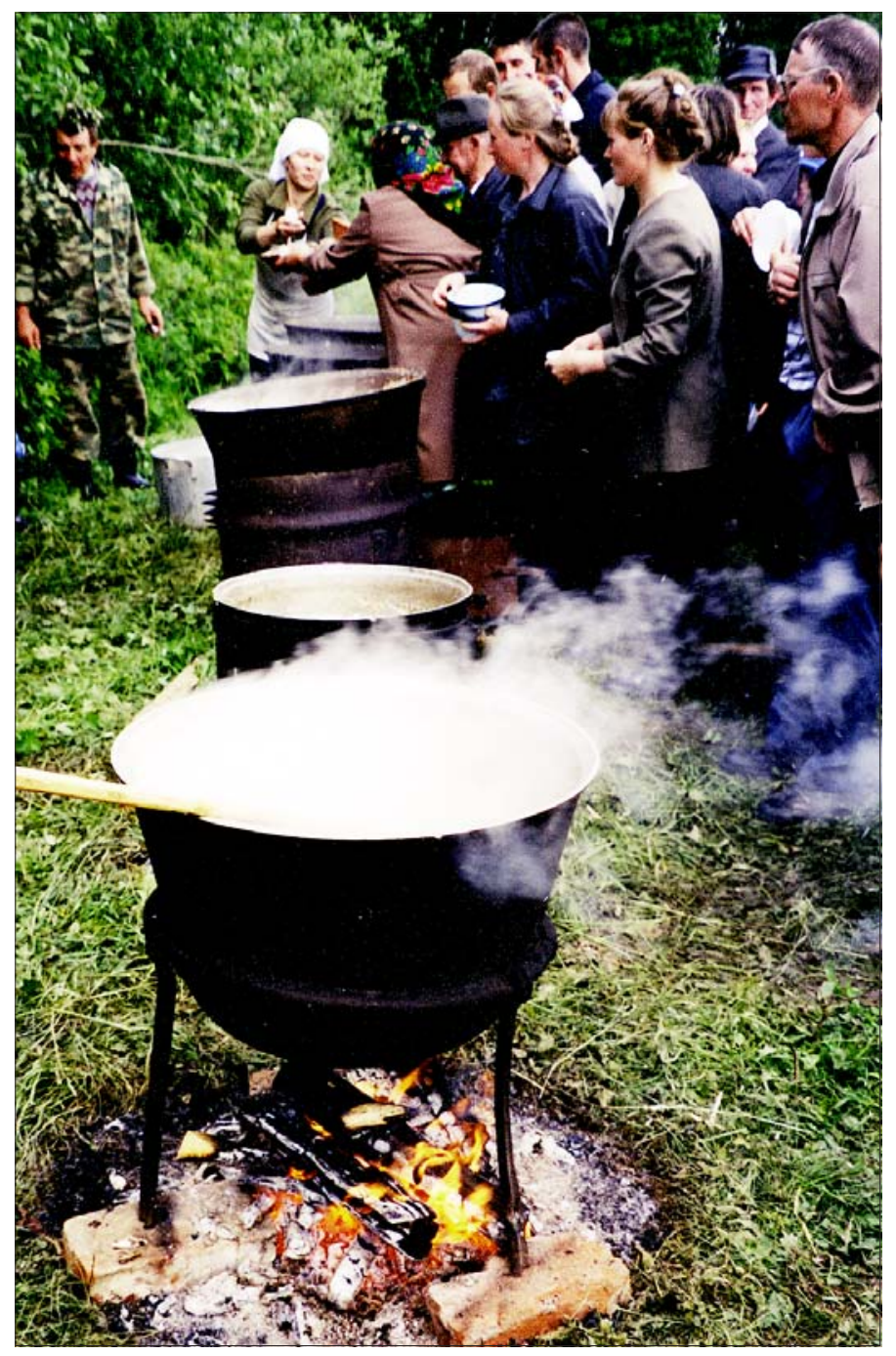

Foto 3. Ohvripudru keetmine suviseks kurbani palveks Jari rajooni Vortsa külas 2004. aastal. Jelena Popova foto. 
ma- ja damianipäevaks (1./14. november) püüti lõpetada sügisesed ohverdused ja palved. Talv algas suurmaarjapäevast (pokrov), mil korraldati aasta viimased surnute mälestamised. Pärast seda ei tohtinud enam karjas käia, sest leiti, et pärast suurmaarjapäeva suundub aasta talve ja karja valvanud čaššakuzjo juba magab. Talve käsitleti kui looduse uinumise aega: $m u z^{\prime} j e m$ uz'e 'maa magab'.

Samasuguseid kalendaarseid perioode on uurijad täheldanud ka teistes põllundustraditsioonides (Vinokurova 1994: 24; Tšernõhh 1999: 14-17). Sesoonse jagamise alus ei ole sel juhul otseselt aastaaegade vaheldumine, vaid sellest tingitud põllutööde tsüklid (Tokarev 1983: 4). Aasta jagamine palju lühemateks ajavahemikeks näitab hooaegade erinevat pikkust. Kõige pikem aeg oli talv, lühim aga suvi, mis kestis natuke üle kuu.

Seoses aja ja hooaegadega on täheldatav kahe poolaasta - suvise ja talvise vastandamine. Seda binaarset opositsiooni on rõhutatud nii talvise ja suvise pööripäeva kui ka ilmatarkustega. Arvati, et lumine talv ennustab vihmast suve, soe külma, aga külm sooja. Ettekujutus talvisest ja suvisest poolaastast ning talvekuude vastandamine suvistele oli omane ka udmurtidele (Vereštšagin

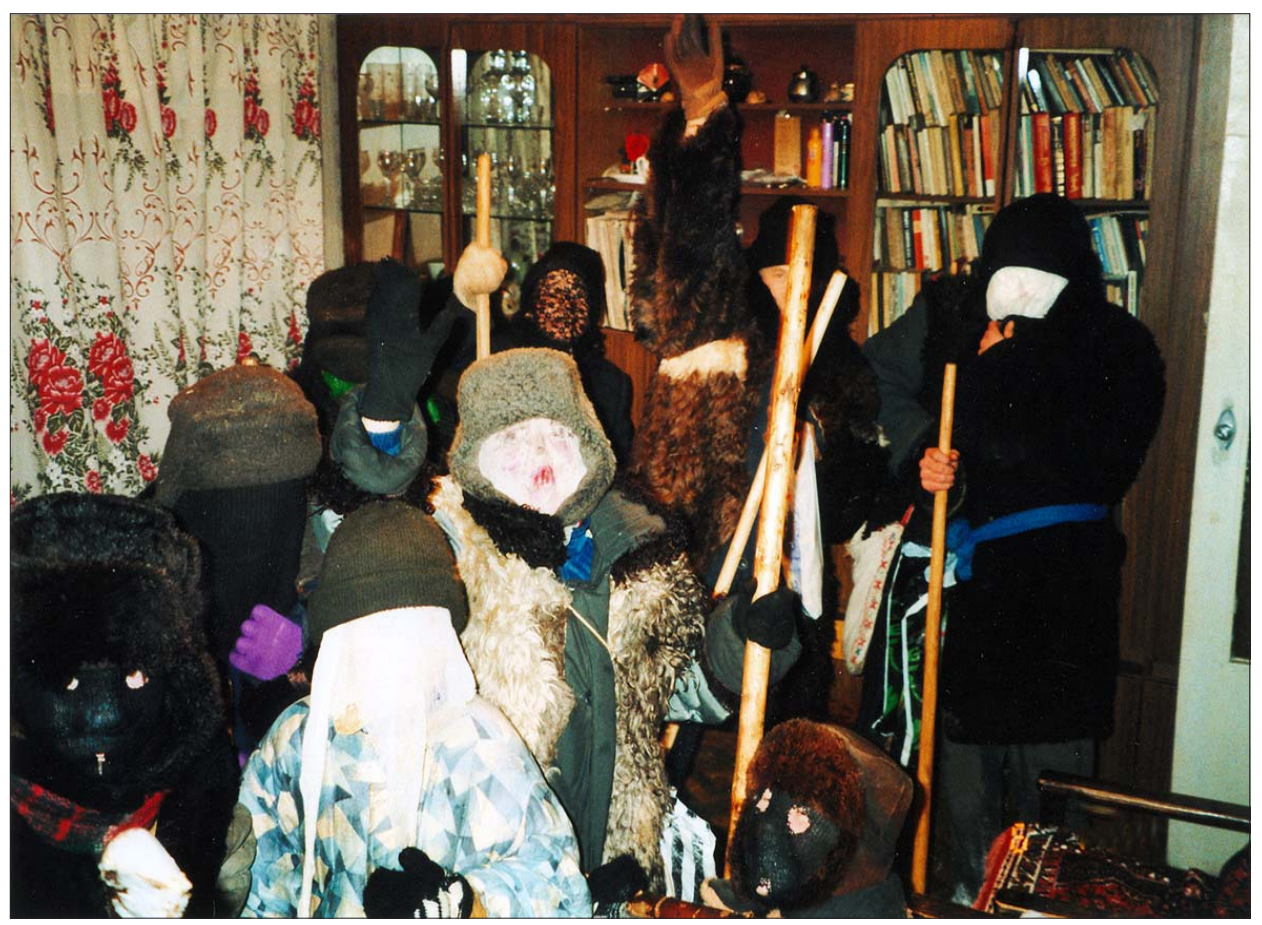

Foto 4. Vožo-sandid Jukamenskoje rajooni Žuvami külas 2001. aastal. Jelena Popova foto. 
1889: 71-71). Ümbritseva keskkonna muutumisega seotud aja mõõtmise mooduseid ja aasta jagamist kaheks poolaastaks on etnograafid täheldanud maailma eri paigus (Zlatkovskaja 1983: 24).

Aasta jagamine hooaegadeks eeldas, et talupojad tegid ilmavaatlusi ja jälgisid päikese kõrgust horisondil eri aastaaegadel. Aastatsüklis eristati talvist ja suvist pööripäeva, sügisest ja kevadist pööripäeva. Kevadine pööripäev on 20. (või 21.) märtsil, kuus kuud pärast sügisest pööripäeva 22. (või 23.) septembril. Talvine pööripäev on 21.-22. detsembril, sellele ajale langevad ka aasta kõige lühem päev ja kõige pikem öö. Suvisel pööripäeval, 21.-22. juunil on päike horisondi kohal kõige kõrgemal: sel ajal on kõige pikemad päevad (vt lähemalt Klimišin 1990: 37). Talvise pööripäeva kohta öeldi nunal berekčeke 'päev läheb tagasi', st lüheneb. Nagu juba märgitud, kutsuti suvist pööripäeva gerber või nunal berte 'päev tuleb tagasi', st pikeneb. Kevadist ja sügisest pööripäeva peeti staatiliseks ajaks - nunal pukon dəิr 'aeg, mil päev on paigal', nunal puke 'päev on paigal'. Valge aja pikenemist ja lühenemist väljendati mõistetega nunal vakči pala karis'ke 'päev liigub lühemale küljele', nunal tol pala karis'ke 'päev pöördub talve'. Viimast vormelit kasutati sagedamini siis, kui jutt oli märgatavalt lüheneva valge ajaga päevast. Alles pärast talvist pööripäeva kasutati väljendit päev tuleb tagasi, st saabub.

Talvise ja suvise pööripäevaga seostusid mitmed olulised kalendrikombed, mis rõhutasid aasta tsüklilisust ja aja naasmist. Aja liikumine on nagu pöörlemine (Lvova \& Oktjabrskaja \& Sagalajev \& Usmanova 1988: 54). Kahe maaharijale olulise perioodi vastastikune suhe on seotud ettekujutusega mütoloogilistest olenditest. Siinkohal märgin vaid talvise ja suvise pööripäevaga seotud uskumust, mille järgi aasta jaguneb vožoks ehk talveks ja gužem vožoks ehk suveks ning kaks korda aastas (talvisel ja suvisel pööripäeval) tulevad lagedale vožo-olendid. 20. sajandi materjalide põhjal langevad need päevad talvel kokku talsipühade ehk jõuluajaga (vene $\mathrm{k}$ свяпочная неделя, сВяпки; 25. detsember - 5. jaanuar / 7.-18. jaanuar), suvel aga gerberiga. Talvel on vožod aktiivsed õhtuhämarusest koiduni, suvel aga keskpäeval. Nad on ohtlikud just mainitud ajavahemikus, eriti siis, kui rikutakse aastaajale vastavaid ruumilis-ajalisi keelde. Talvel pesitsevad vožod rehe all, aitades, saunades või tühjaksjäänud majades, suvel käivad rukkipõllul. Nad tulevad ja lahkuvad jõge pidi. Erinevalt talvisest peetakse suvist pööripäeva kui õitseaega tugevaks aastaajaks. Seda on võrreldud inimese õitsengu ja füüsilise küpsusega.

Põllu- ja majapidamistöid, kalendritähtpäevi, pühasid ja argipäevi järjestav aastatsükkel reglementeeris ka külaühiskonna sotsiaalse elu. Kõige eredam näide on pulmade pidamine. Kõige rohkem abielusid sõlmiti talvel (peamiselt jaanuaris ja veebruari esimesel poolel) ning sügisel (oktoobris ja novembri 


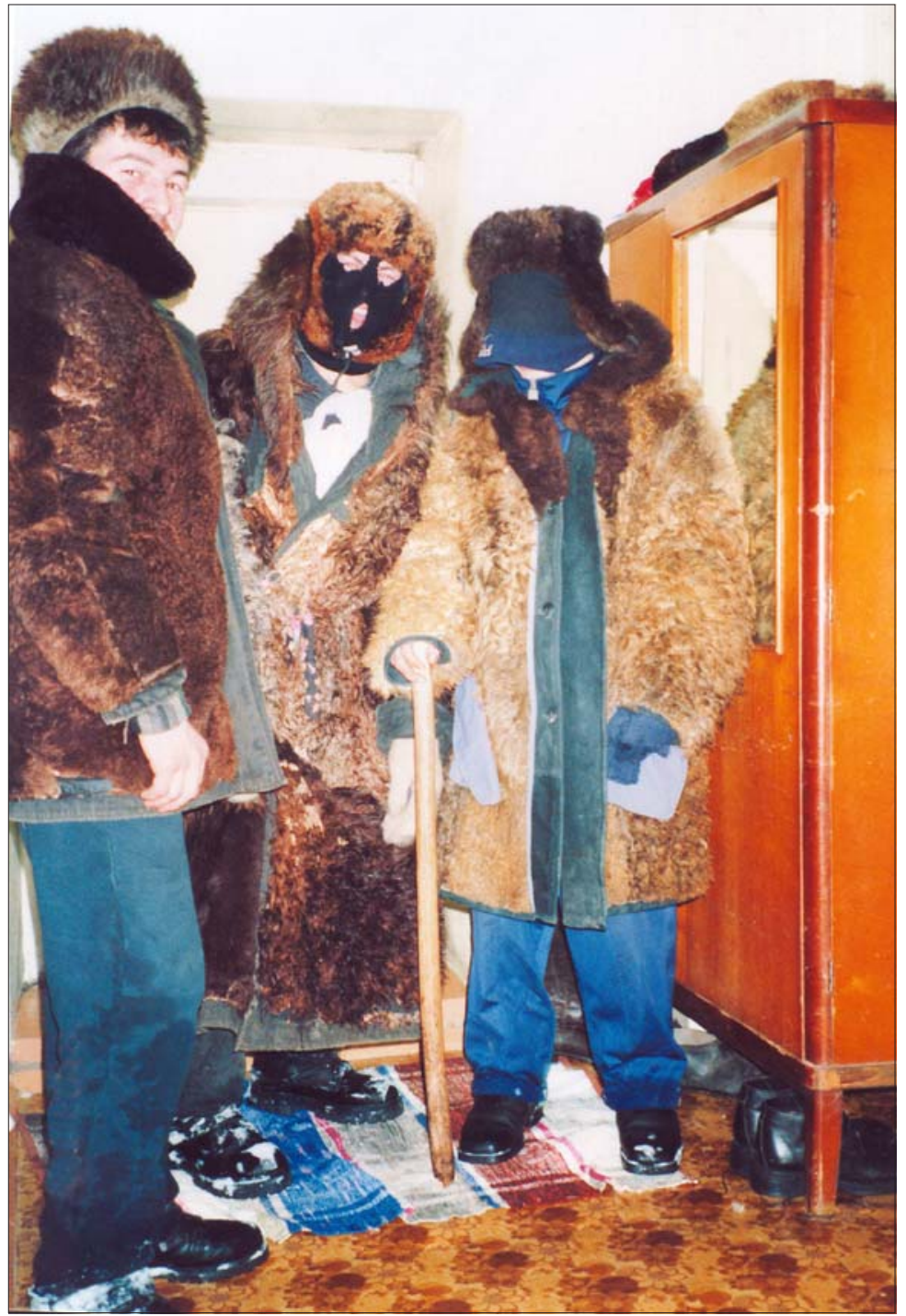

Foto 5. Vožo-sandid Jukamenskoje rajooni Žuvami külas 2002. aastal. Jelena Popova foto.

alguses). Suvel ja sügise alguses, peamiste põllutööde ajal, vähenes pulmade hulk märgatavalt. Pulmi ei korraldatud kalendaarsete surnute mälestamise päevade, ühispalvuste ja ohverdamiste päevadel, paastuajal, õigeusu ja koguduse pühadel. Pulmade jaotumise aastaanalüüs meetrikaraamatute (19161918) põhjal näitas, et 53\% pulmadest peeti jaanuari-ja veebruarikuus, $25,2 \%$ aprilli lõpust juuli keskpaigani ja 10,1\% septembri lõpust ja oktoobri algusest novembri keskpaigani (Popova 1998: 115). Märtsis, detsembris ja suvekuudel 
pulmi peaaegu ei peetud. Talvel ei peetud pulmi alates jõulupaastust veeristsete ehk jumalailmumispühani (st kolmekuningapäevani; 6./19. jaanuar). Pulmapidamist ei tulnud ette ka suure paastu ja lihavõtete ajal, samuti külvi- ja heinatööde ning viljalõikuse paiku. See seletab ka, miks pulmi ei peetud augustis ja septembri esimesel poolel. Vähesed suvised pulmad peeti külvitööde lõpu ja suviste põllutööde vahel, jättes vabaks apostlite ehk peetripaastu (suvistetest peetripäevani) ning suvise peetripäeva (ka peeterpaulipäev ehk peeterpaavlipäev; 29. juuni / 12. juuli). Samasugune oli pilt 19. sajandi lõpus ja 20. sajandi alguses Volga-äärsete venelaste juures (Zorin 1981: 48-54). Enamvähem sel viisil käituti 1930. aastate lõpuni.

Praegu peetakse maal pulmi põllutöödest enam-vähem vabadel aegadel. Õigeusu kalendrit järgitakse osaliselt. Pulmi võib pidada isegi paastuajal, viimast peaaegu ei peetagi. Siiski püütakse vältida pulmapäeva sattumist lihavõtetele ja teistele olulistele õigeusu pühadele.

\section{Rahvaastronoomia ja kalender}

Aeg kui traditsioonilise maailmamudeli oluline komponent kajastus ka rahvaastronoomias. Taevakehad on mütoloogia põhjal ammu loodud maailmakorra elemendid, mistõttu paljud ajalised parameetrid on seotud lunaarsete ja solaarsete uskumustega.

Ööpäeva valge aja jagamine ajalõikudeks on seotud päikese asendiga horisondi suhtes. Päeva raames määrati aega sarnaselt teiste rahvastega (Vladõkin 1994: 222-223; Vinokurova 1994: 15) vastavalt päikese liikumisele horisondil. Õhtuhämaruse saabumist ja loojangut seletati sellega, et päike läks maa taha või varjus maa alla või sai vanaks. Näiteks udmurtidel, bessermanidele kõige lähedasemal rahval, oli käibel ettekujutus, et ööseks peidab päike ennast maa alla või maailma lõpus asuvate suurte mägede taha (Moškov 1900: 197). Vanematel inimestel oli kombeks loojangust rääkides öelda, et päike veereb, mitte laskub. Päikese peale ei tohtinud näidata näpuga, seda ei tohtinud uurida, tema poole ei tohtinud vaadata hädas olles. Oletati, et keeldude rikkumine toob kaasa liigeste paistetuse, kiskmed ja ajab sõrme umbe.

Iga tavatut nähtust selle taevase valgusallika liikumises, näiteks varjutust, tõlgendati kui kataklüsmi ja ammustel aegadel rajatud maailmakorra rikkumist. Näiteks osalist või täielikku päikesevarjutust seletati sellega, et šaitan on päikese rikkunud või varastanud. Udmurdid arvasid, et päikesevarjutus tekib sellepärast, et taevakeha vananeb nagu inimene, aga pärast sünnib taas (Moškov 1900: 197) või varastab päikese kuri vaim Ubir (Vereštšagin 
1889: 139). Päikesevarjutuste kohta oli udmurtidel ka selline seletus: valitseja sõitis ära, sellepärast veeres kaasa ka päike (Vereštšagin 1889: 139).

Jälgides päikest tõusu ja loojumist ning pühade ajal ennustati lähiaja ilma. Näiteks punaselt tõusev päike ennustas vihma (AVM < Jukamenskoje raj, Šamardani k-Z.T.V. (2000)), selge päikesetõus lubas päevaks head ilma, pilvine vihma (AVM < Jukamenskoje raj, Žuvami k - P.V.P. (2003)). Mitut järjestikust vihmast suve seletati päikese muutumise ja uuenemisega: šundəิ voščeke.

Traditsioonilises ajaarvestuses oli tähtsal kohal kuutsüklite jälgimine. Kronoloogilist perioodi, mis võrdub nelja kuufaasiga, kutsuti kuuks ( $\breve{t o l e z}$ '). Faaside vaheldumine võimaldas pidada ajaarvestust ning see kajastus arusaamades ja majandustegevuses. Kuu loomine toob taevasse kitsa kuusirbi, millest umbes seitsme päeva pärast saab poolkuu. Seda aega nimetatakse esimeseks veerandiks. Umbes kaheksa päeva pärast saabub täiskuu ja veel seitsme päeva pärast on käes viimane veerand, mil kuu on taas kitsas sirp, kuid kaardus juba teisele poole (vt nt Klimišin 1990: 62).

Kuu neli faasi olid ka mitme bessermanidele tuntud traditsioonilise ajaarvamissüsteemi aluseks. Kalendrikuu olulised tähised olid just need faasid: noorkuu, esimene veerand, täiskuu ja vanakuu. Kuu faaside muutumine võimaldas eristada nelja lühikest ajavahemikku, mille nimetused olid vastavalt esimene veerand - tolez' bude 'kuu kasvab', vil' tolez' pote 'uus kuu tuleb välja'; täiskuu pgolez' bâgâl' čekiz 'kuu läks ümmarguseks', târo pgolez' 'täiskuu', vil' pgolez' 'uus kuu'; kahanev kuu - ̌̌olez' bâre 'kuu kaob', vil' pgolez' bâre 'uus kuu kahaneb', tolez' peres'me 'kuu vananeb'; kuuloomine - ‘̆olez' vorz'eke 'kuu sünnib', tolez' vis 'kuude vaheaeg'. Taevase valgusallika välised muudatused andsid ainest mõistatusteks. Täiskuu ajal kutsuti teda taldrikuks, ümmarguseks leivakakuks, kahanemise või esimese veerandi ajal ümberlükatud künaks või sirbiks.

Aega, mil hakkas paistma uus kuusirp, loeti järgmise kronoloogilise ajajärgu alguseks. Kuufaaside vahetust seletati taevakeha vananemise ja taassünniga. Seda kinnitab ka eespool toodud sõnavara. Kuufaasidest rääkides on üldkasutatavad elutsükli terminid noor ja vastsündinu noore kuu puhul ning vana kahaneva kuu korral. Arvati, et noorkuu on tugev ja kahanev kuu nõrk. Binaarse opositsiooni moodustavad siin karakteristikud noor - vana, tugev nõrk, samamoodi nagu ka inimese vanuselises gradatsioonis on noor tugev, vana aga nõrk. Tänapäeval on kuu vananemise - tolez' peres'miz 'kuu jäi vanaks' - ja sündimise - tolez' vorz'ekiz 'kuu sündis' - käsitlus märksa rohkem kasutusel kui kuu nelja faasi eristamine.

Kuuvaatlused kajastusid ka rahvaluules, mis selgitasid kuu plekkide teket. Levinud on süžee kuul olevast inimesest - kaelkookudega tüdrukust või naisest. 
Seal istub kaelkookudega inimene. Kaelkoogud on tehtud sellised, no kõvasti koolutatud. [---] Varem küsiti, kust inimene sinna sai, aga ma ei tea, kuidas ta sinna sai. On seal inimene, kaelkookudega. Kaelkoogud on õlal lookas, on ämbrid. Võib-olla oled näinud? Talvel selge ööga on ta hästi näha (AVM < Jukamenskoje raj, Šamardani k - Z.T.V. (2000)).

Kunagi ammu elas orvuke. Onudel ei olnud temast kahju. Ülekohtu pärast nuttes läks tüdruk vee järele ja kuud vaadates lausus: "Kui kuugi mind enda juurde võtaks!" Pärast seda kostis taevast hääl: "Siin on väga külm, võimatu ellu jääda.” Tüdruk ei kartnud isegi külma ja palus inmarit, et see ta siit ära viiks. Kohe kadus ta mäe pealt ja ilmus kuule. Sellest ajast peale räägivad bessermanid, et kuu peal seisab tüdruk ämbritega (Antuganov 1920ndad: 30).

Samalaadseid tekste on eri aegadel üles tähendatud ka udmurtidelt (Potanin 1884: 222; Pervuhhin 1888: 15-16; Vereštšagin 1886: 85) ning need kajastuvad veel mitmes traditsioonis (vt nt Konakov 1996: 33-34; Toidõbekova 1997: 100).

Päevase aja määramisel oli oluline vaadata päikeseketta asukohta taevavõlvil horisondi suhtes.

Kuu igal faasil oli oma semantiline tähendus, nende järgi seati majapidamistööde rütm, kombed ja igapäevane käitumine. Kuuga seotud keelud, käsud ja ended muutuvad aktuaalseks just uue faasi saabumisega. Noorkuu suurust mõõdeti silma või sõrmede laiusega: selle kasvu kohta öeldi, et kuu on sõrmelaiune või kaks sõrme lai. On kombeks öelda, et kuu sünnib, või nagu päikesegi kohta, et ta tõuseb, aga viimases faasis sureb või kaob. Uut kuud püüti märgata endast paremal, arvates, et see toob edu, vasakult aga haigust ja nälga. Et mitte kogemata näha kuud endast vasakul, püüti sel ajal taevasse mitte vaadata (AVM < Jukamenskoje raj, Žuvami k - P.N.E. (2003)). Vanemad inimesed hoiatasid lapsi, et nad sel ajal taevast ei uuriks, vaid vaataksid rohkem maha.

Noorkuud märgates võeti pihku leib, raha, taskute sisu. Kui mitte midagi käe alla ei sattunud, suruti taskus käed rusikasse, justkui hoitaks midagi peos. Noorkuu ajal katsuti jälgida, et taskud oleksid täis, võeti kaasa raha või leiba. Kuud nähes pöörduti tema poole ja öeldi:

Olgu elu leivaga! Olgu mu elus raha! (n'an'en med ulomâ, kon'd'onen med ulomâ) (AVM < Jukamenskoje raj, Žuvami k - V.L.A. (2003));

Tulgu me elu selline! Olgu elu raha ja nõelaga! Leiva ja veega tulgu elu! (ten tače med ulom, kon'd'onen-ven'en med ulom, nan'en-vuen med ulom!) (AVM < Jukamenskoje raj, Žuvami k - V.L.A. (2003)); 
Leib ja sool! (N'an no slal!) (AVM < Jukamenskoje raj, Šamardani k Z.T.V. (2000)).

Nõelad ja raha tähendasid külluslikku elu, leib ja sool täis kõhtu. Keelatud oli kuu ilmumist vaadata ja kommenteerida - kui seda teha, kulub eeloleval kuul toiduaineid ja leiba ülemäära. Kuni noorkuu oli veel sõrmelaiune, löödi tema poole risti ette ja paluti õnnistust kalendrikuule.

Kahaneva kuu aega peeti halvaks, sellepärast ei alustatud sel ajal uut tööd, majaehitust ega külvi ning ei aetud karja välja, naised ei loonud kangast ega alustanud kudumist, ei pöetud ka lambaid, kartes, et vill jääb lühikeseks. Peaaegu tühjaks või üleminekuajaks peeti kuuloomist. Arvati, et sel ajal ei onnnestu isegi samagonn, ega tahetud sedagi ajada (AVM < Jukamenskoje raj, Žuvami k - P.N.E. (2003)).

Kuuvarjutust nagu päikesevarjutustki peeti erakorraliseks nähtuseks ja öeldi, et taevakeha on rikkunud šaitan või nõiad; selles nähti maailmalõpu ennet. Analoogilisi seletusi võib kohata ka udmurtidel, kes näiteks arvasid, et nõiad rikuvad spetsiaalselt kuud, sest ta paistab ja segab neid inimesi söömast (Moškov 1900: 197).

Kuufaaside vaatlused oli levinud rahvameteoroloogias. Väliste muutuste põhjal ennustati eelseisva nädala ja kuu ilma, viljasaaki, külviaegu. Kui uus kuu ilmus kohe suurena ja sirp oli kaldus, usuti tulevat vihmast ja kehva ilmaga kuud. On teada enne, et kuuvahetusega kaasneb alati õnnetus:

Kui algasid vihmad, öeldi, et nähtavasti hakkas kuu kahanema $(\mathrm{AVM}<$ Jukamenskoje raj, Ježovo k - B.Z.L. (2003)).

Kuu ja päike kui maailmakorralduse olulised elemendid kajastusid ka udmurtide uskumustes (Vladõkin 1994: 67-69; Popova \& Tšernõhh 2003: 281283), mis olid olemuselt üsna sarnased bessermanide pärimusele.

Aega ja ilma määrati ka tähtede kiz'il'i järgi. Tavaliselt jälgiti Suure Vankri tähtkuju, mida nimetati Kobəิ (Kopsik) või Siz'âm kiz'il'i (Seitse tähte). Kui tähed olid talvetaevas, oodati selget ja külma ilma, suvel aga kuiva. Paastuaegne tähistaevas ennustas head viljasaaki. Tähtede ilmumine taevasse ja nende asend võimaldas määrata koidiku lähenemist ja ööaega. Paljud informandid märkisid, et tänapäeval on need oskused unustatud - neid vajati siis, kui kella polnud.

Loodusliku tasakaalu ja ammustel aegadel loodud harmoonia rikkumine tõi kaasa kaose ja maailmamudeli ebastabiilsuse. Kooskõla ajaparameetriga tagas ideaali ja keskkonna stabiilsuse. Inimene arvas, et ta suudab oma tegevusega mõjutada tuleviku kvaliteeti (Lvova \& Oktjabrskaja \& Sagalajev 


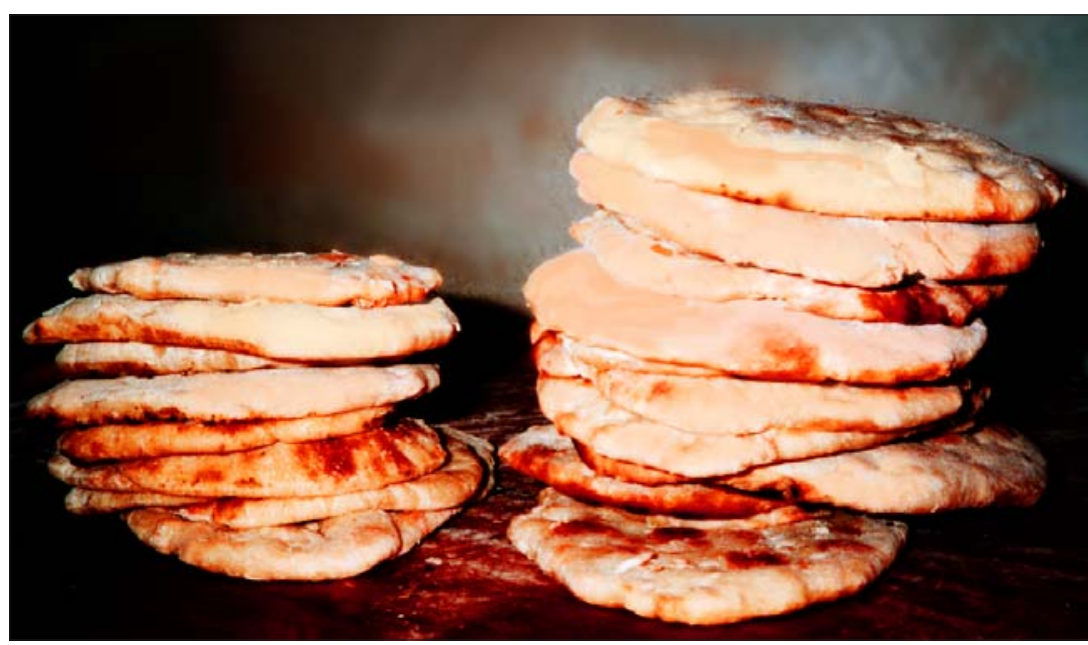

Foto 6. Vožo-santide kostitamiseks küpsetatud kuarnjanid Jukamenskoje rajooni Žuvami külas 2003. aastal.

\& Usmanova 1988: 55). Loodus- ja kliimaanomaaliaid ning halba ilma käsitleti sageli maailma lõpu ennetena, varasema harmoonia rikkumise puhul oletati, et rahvas on muutunud halvaks ja ilm läheb hukka või ilm tusatseb - korda ei ole enam või kas tõesti maailma lõpp: suvi on tänavu külm. Nii moodustavad looduslikud kliimakarakteristikud osa traditsioonilisest ajaja kalendripildist.

\section{Aja mõõtmise moodused}

Rahvapärimus teab mitmeid aja mõõtmise viise. Valge päevaga määrati aega silmaga päikese asendi järgi. Igapäevases elus võis sageli kuulda, kuidas räägiti teatud ajavahemikest: šundà čuk palaja 'päike on hommikus', šundâ obed palan 'päike on lõunas', šundâ obed šorân 'päike on keskpäevas', šundâ vâlân na 'päike on veel kõrgel', šundô žât pal koškiz 'päike läheb õhtusse', šunds puks'e n'i 'päike vajub'. Selline ajamääratlus oli laialt levinud paljudel rahvastel (Žukovskaja 1986: 131; Svjatski 1966: 103-104). Tutvus mehaaniliste kelladega tõi kaasa uue võtte: taevavõlv jaotati vastavalt kellale tinglikult ühesugusteks vahemikeks, kus kõige kõrgem punkt, mil päike oli seniidis, vastas kella kaheteistkümnele päeval. Sama tava täheldas 19. sajandi vene talupoegade juures ka Daniil Svjatski (1966: 103).

Mainitud ajaarvamisvõtted on seotud selliste tähtsate kronoloogiliste ajavahemikega nagu ööpäev ja valge päev. Päikese asendi jälgimine taevalaotu- 
ses ning tõusu- ja loojangupunktid olid hooaegade kindlaksmääramise aluseks. Näiteks jälgiti päikese kõrgust taevas keskpäeval (suvel kõrgel, talvel madalal), samuti päikese tõusu- ja loojangupunkti nihkumist põhja või lõunasse eri aastaaegadel: kevadel tõuseb päike ühest punktist, sügisel teisest, ka talvel ja suvel need punktid nihkuvad. Enamasti lähtusid vaatlused talus ühest punktist. Näiteks kevadel tõusis päike teatud puu tipust või künkalt, suvel oli selliseks kohaks hoopis org, sügisel naabri katus, talvel aga teine puu või salu. Siit tuleneb ka enne ja pärast suvist pööripäeva sageli kasutatav mõiste šundô berekčekiz 'päike pöördus ehk vahetas kohta'. Kui tõusu- ja loojangupunkti muutus oli ilmne, öeldi, et päike tõuseb või loojub teises kohas. Samu võtteid aastaaja määramisel võib kohata paljudes rahvakalendrites (Klimišin 1990: 150).

Päevavalges määrati aega sammudega, mõõtes oma varju või kindlate objektide (puud, ehitised) varju pikenemist ja kahanemist. Lühim oli vari keskpäeval, pikim pärast keskpäeva ja õhtutundidel. Oma varju järgi määrati aega järgmisel põhimõttel. Näiteks seisti nii, et vari langeks tasasele pinnale, ja märgiti koht, kus see lõppes. Seejärel mõõdeti selle pikkus sammude või tallapikkustega. Tavaliselt öeldi sellisel juhul, et aeg on viis sammu või vari pöördus või aeg on lõunas - vari jäi lühemaks. Neid võtteid kasutati laialdaselt põllutööde ajal.

Päike näitab ka praegu kellaaega. Päike tuli välja ja mõne aja pärast juba mõodeti varju. Vaatad, kui pikk on sinu vari: üks samm, kaks sammu, kolm, neli, viis. Ongi kell. Päikese järgi mõõdeti kella (AVM < Jukamenskoje raj, Žuvami k - N.Z.S. (2003)).

Päikese järgi vaadati. Kuhu päike liikus. Lõunat [keskpäev - J.P.] vaadati päikese järgi (AVM < Jukamenskoje raj, Ježovo k - B.Z.L. (2003)).

On veel üks moodus, mida lapsed kasutavad tänapäeval naljaviluks, kuid veel mõni aeg tagasi kasutasid seda ka täiskasvanud. Käelabad sirutatakse kõrvuti ette paralleelselt maapinnaga. Võetakse väikese sõrme pikkune pulk või rohukõrs ja pannakse see sõrmede vahele püsti (vt fotod $7 \mathrm{a}$ ja $7 \mathrm{~b}$ ). Võtte aluseks on päikesekella põhimõte: vaadatakse, mitu sõrme lõikub pulga varju. Seda võtet kasutasid tavaliselt karjused ja talupojad põllutööde ajal. Hiljem kohandati seda ajanäitajat mehaanilise kellaga: ühe või kahe ja poole sõrme pikkus vastas kella ühele pärast lõunat.

Talupojad meisterdasid ka palju keerukamaid seadmeid, mille aluseks olid eeltoodud võtted. Näiteks Jukamenskoje rajooni Filimonovo küla elanikud mäletavad kohaliku külasepa tehtud kella: meister tagus sepikoja aknale nae- 
lad, paigutades need sellise vahemaaga, et keskmise naela vari täitis mehaanilise kella osuti rolli, mis liikus vastavalt päikese liikumisele ja langes sihverplaadile. Ümber sihverplaadi taotud naelte vahemaa vastas mehaanilise kella tunnijaotusele. Kellatundmine ja tark arvestus võimaldasid külasepal luua sellise omalaadse ajanäitaja (AVM < Jukamenskoje raj, Filimonovo k Z.N.A. (2000)). Väikesest kepist ja sälkudega lauast valmistatud kella on uurijad näinud Kesk-Uurali vene talupoegadel (Tšagin 1998: 64) ja permikomidel, kes kasutasid sihverplaadiks ratast (Tšagin 2003: 417).

Päevasel ajal mõõdeti eluruumis päikesekiire liikumist põrandal ja mööblil, mida väljendati määratlusega: päike on keset tuba, varsti on keskpäev või päike langes ahjule (pingile), varsti aetakse kari koju või päike läks voodile, on aeg ahju kütta. Seda meetodit mainivad informandid üsna sageli.

Päike tuleb aknasse päeva [lõuna - J.P.] suunast - tarvis hakata lõunat tegema. Vanemad tulevad juba sööma. Kust meie teame, mis kell on? Külas elati ilma kellata (AVM < Jukamenskoje raj, Žuvami k - N.Z.S. (2003)).

Vastavalt ehitustavale oli majade esikülg asunduses suunatud lõunasse või kagusse. Elamu oli päev läbi maksimaalselt valgustatud ja selline asend võimaldas jälgida päikesekiirte liikumist hommikust õhtuni. Mõistagi tegid planeeringu eripärad iga hoone juures valguse jälgimisel oma korrektiive. Aja arvestamine päikese järgi sõltus ka aastaajast: suvel oli valge päev pikem, talvel lühem ja eri aastaaegadel asus päike horisondil eri nurga all; "päikesekella" võimalusi piiras halb ilm.

1930.-1960. aastatel löödi paljudes külades vastavalt tundide arvule tuletõrje häirekella. Külaelanikele olid ajaorientiiriks ka kohalike lennuliinide lennukid, mis tavaliselt lendasid iga päev kindlal ajal ja võimaldasid kellaaega teada saada: lennuki järgi saime aja teada või lennuk pole veel läinud lõunat on vara teha või kui lennuk läheb - see on kella nelja paiku -, tuleb loomi toita.

Öösel teatasid aega kuked. Oletati, et kuked kirevad keskpäeval, umbes kolm tundi pärast südapäeva, keskööl, keset ööd ja enne koitu või iga tund. Arvati, et nad teavad ise, millal on aeg kireda või kui neil hakkab talla alt sügelema, on aeg kireda. Kukelaulu valel ajal peeti halvaks endeks. Udmurtide arvates on sellel linnul peen kuulmine ja ta teeb noka lahti alles pärast maa-aluseid kukki, jäljendades neid (Vereštšagin 1889: 140). Viimasel ajal on bessermanidel tekkinud arvamus, et vana kord (traditsioonid) on maailmas rikutud, sellepärast on kukk hakanud ajaarvestuses eksima ega laula enam nii täpselt kui varem. Ka üleminek suve- ja talveajale, mis ei ole kooskõlas 
looduse loomuliku ajakorraldusega, eksitas kukkede laulu. Udmurdid seletasid kukkede laulurütmi häireid nii:

Öeldakse, et kuked laulsid varem kell kümme, aga nü̈d laulavad kell üksteist; arvame, et see ebausk on omandatud venelastelt, kes ütlesid, et kuked hakkasid hiljem laulma sellest ajast peale, kui inimesi hakati soldatiks vôtma (Vereštšagin 1889: 71).

Nii et ka talurahva elu mõjutanud sotsiaalsed faktorid võisid rahva arvates rikkuda aja normaalset kulgu.

Ajaarvamiseks kasutasid talupojad ka perioodiliselt korduvaid sündmusi ja mingi töö tegemiseks vajalikke ajavahemikke. Näiteks vee keema ajamiseks kuluvat aega ahjupotis vu berektitčoz' ja samovaris samovar berektitčoz', supi valmistamise aega šâb vuitčoz', puude põlemise aega ahjus gur žuatčoz', leiva küpsetamise aega n'an' pâžtčoz', lehma lüpsmise aega skal kâskitčoz', peeru põlemise aega čag žuatčoz', tubaka suitsetamise ja põllu kündmise aega. Ajaarvestuse aluseks võis olla ka mingiks tegevuseks vajalik aeg. Näiteks viivust rääkides öeldi šokčitčoz' 'kuni sisse hingad', $k \hat{\partial}$ n'šštitčoz' 'kuni silma pilgutad'. Katlas vee keemise, tubaka suitsetamise või üldtuntud lihtsa roa valmistamisega seotud ajavahemikud on aidanud aega arvestada ka teistes kultuurides (Petrova 1937: 111; Žukovskaja 1986: 132; Sokolova 1990: 87).

Bessermanidel on ajaarvamisühikutena tuntud veel sellised ajavahemikud nagu supi ja tee keetmise ning leiva küpsemise aeg. Need olid ajaühikud, millega puutusid kokku paljud. Sageli tehti neid toiminguid päeva jooksul korduvalt ning nende kestus oli selgelt fikseeritav. On märkimisväärne, et ajaloolises pärimuses, kus on juttu kauge aja tagustest sündmustest ja vägilastega asustatud maast, kasutatakse ajaühikuna sageli toiduvalmistamise, leiva jahtumise, lõkke põlemise ja vee keetmisega seotut. Selliseid näiteid võib leida udmurtide pärimustes, eriti vägilasmuistendites (Bogajevski 1892: 173-174; Kralina \& Pozdejev 1971: 102, 128). Aeg, just nimelt lühike ajavahemik (nii ruttu, et vesi ei jõudnud katlas keema minna või isegi leib oli veel kuum) kinnitab siin ühest küljest üleinimlikke võimeid, teisest küljest mõõdab kiirust ja vahemaad. Mainitud ajamõõtmistavad on säilinud bessermanide olmelises sõnavaras, pärimustekstides ja bõlitškades, mille süžeed on seotud tuntud mütoloogiliste tegelastega, kes rõhutavad jutustatava süžee sakraalsust ja eristumist olmesfäärist.

Tähtsad sündmused, mille aega arvestati kogu aasta jooksul, olid õigeusu pühad, peod, tavandid ja hooajatööd. Pikema ajavahemiku mõõtmisel (sajand, inimese elu) lähtuti olulistest ajaloosündmustest ja loodusõnnetustest (põud, rahe, külm suvi) või vilja-aastatest. Perekonna ja suguvõsa raa- 

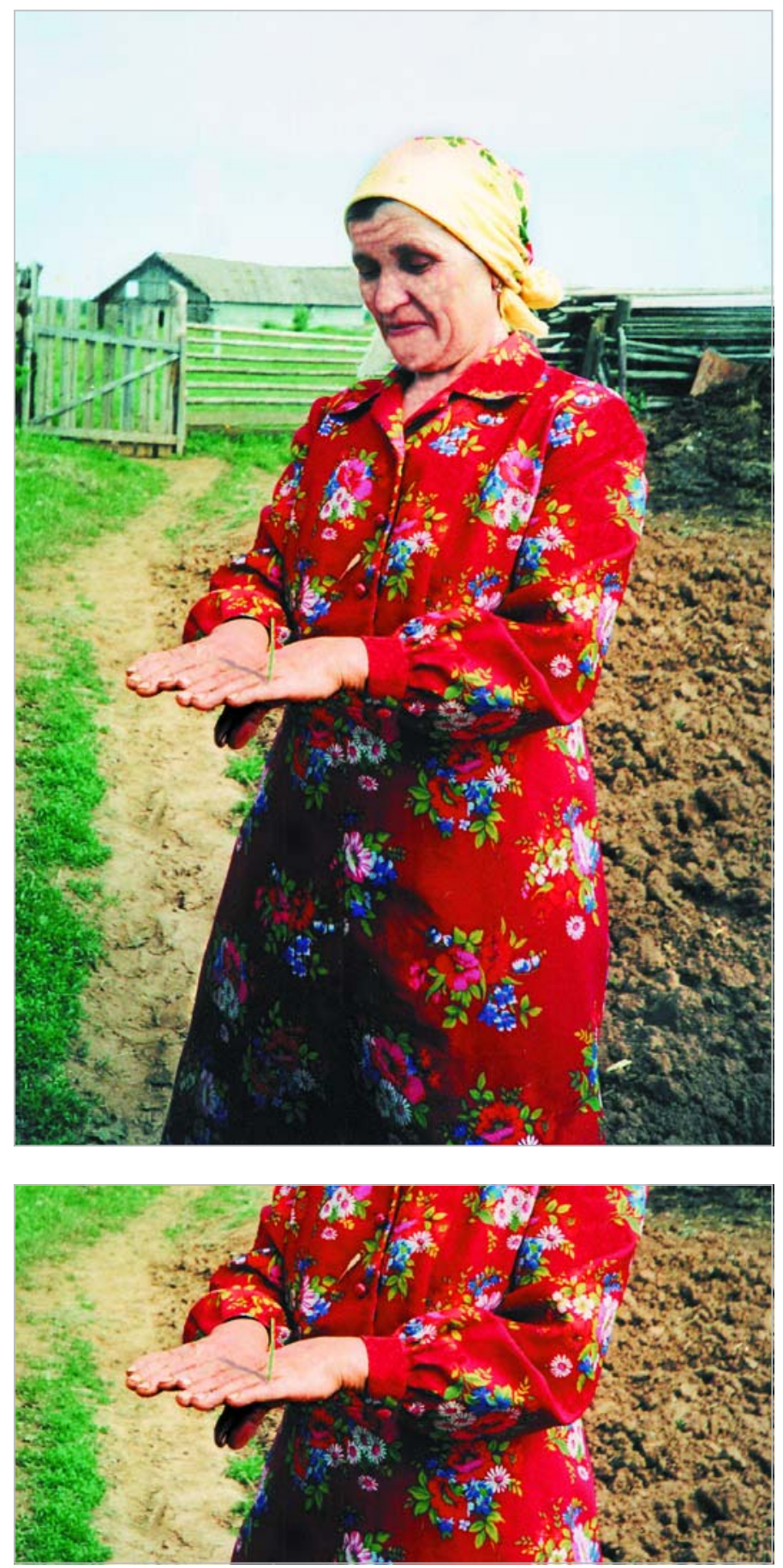

Fotod 7 a ja $7 b$. Aja arvestamine varju ja rohukórre abil Jukamenskoje rajooni Tõlõsi külas 2000. aastal. Jelena Popova foto. 
mes võisid ajaarvamise punktideks olla ka kellegi sünd, abiellumine, surm, kolimine, tulekahju. Aja orientiirideks olid ka olulised ühiskondlikud või riiklikud sündmused, mis mõjutasid küla eluolu. Selles plaanis on märkimisväärsed ka tähtsamad 20. sajandi sündmused, mis on meelde jäänud omalaadsete verstapostidena: kodusõda, kollektiviseerimine, Teise maailmasõja (kasutatakse endiselt nimetust Suur Isamaasõda) algus ja lõpp, kolhooside liitmine ja nn perspektiivitute külade likvideerimine, ka perestroika (uutmine).

Juuliuse ja gregooriuse kalender tulid bessermanide olmesse peamiselt ametlike institutsioonide ja õigeusu kaudu. Bessermanide 18. sajandi keskel alanud ristiusustamine ja tutvus õigeusuga on minu arvates toonud traditsioonilisse ajaarvestusse ja maailmapilti tähtsaid uuendusi. Õigeusu kultuur tõi ajaarvestusse mõiste kalender, mis põhines kalendrikuudel, fikseeritud päevadel, sh õigeusu pühadel ja paastudel, mida bessermanid hakkasid hiljem rakendama enam või vähem täpsete orientiiridena koos traditsioonilise ajaarvestusega.

Maaelanike tarvidus ilmaliku kalendri järele kasvas nende lülitumisega riigisüsteemi ja väliskontaktide laienemisel koos administratiivküsimuste lahendamise vajadusega. Aeg kui traditsioonilise maailmamudeli kategooria muutus pärast tutvumist kalendrite ja õigeusu traditsioonidega oluliselt. Peatumata õigeusu kalendri tähtpäevade, palvuste ja rituaalide omandamisel ning piiblisüžeede mõjul bessermanide maailmavaatele ja mütoloogiale märgin, et tutvus õigeusu kalendriga tõi käibele liikuvate pühade mõiste seoses võinädala (maaslenits), ülestõusmispühade, taevaminemispüha ja suvistetega. Kindla kuupäevata liikuvate pühade kohat öeldi nunalez kâstas'ke 'päev/kuupäev venib'. Need, nagu ka õigeusu kalendri fikseeritud tähtpäevad, said uue ajaarvamise aluseks, näiteks: kolm päeva enne suurmaarjapäeva või nädal pärast lihavõtteid. Traditsiooniline süsteem ei andnud muutunud ajaloolises ja kultuurilises olukorras enam aja arvestamiseks vajalikke pidepunkte.

Vaatamata üldlevinud arvamusele, et traditsiooniline ajaarvestus on läbi teinud suure muutumise ja praeguseks kadumas, tuleb toonitada, et välitööde materjalidest nähtub ka mitmete arhailiste olmeliste elementide püsimine. Maaharimine nõuab oskust määrata looduslik-klimaatilisi tingimusi hooajatööde ja nendega seotud majapidamistööde alustamiseks. Sellepärast on aja ja kronoloogiliste arusaamade süsteemis oluline koht teadmistel taime- ja loomariigist, meteoroloogilistel vaatlustel ning maaharija kogemustel.

Tõlkinud Asta Niinemets 


\section{Kommentaarid}

${ }^{1}$ Siin ja edaspidi on udmurdi keele bessermani murdes olevad sõnad ja laused translitereeritud ladina tähestikku vastavalt autori näpunäidetele.

${ }^{2}$ Kurbani ühispalvusel ei ole kindlat aega. See korraldatakse juunis ja päev määratakse külakogukonna ja vanemate inimeste otsusega. Palvus peaks tagama suveks hea ilma.

\section{Arhiiviallikad}

Antuganov 1920ndad = Vene Teaduste Akadeemia Uurali osakonna Udmurdi Ajaloo, Keele ja Kirjanduse Instituudi arhiiv, nimistu 2N, säilik 391.

$\mathrm{AVM}=$ autori (= Jelena Popova) välitööde materjalid (informandid on identifitseeritud initsiaalidega).

Bijanova 1946 = Vene Teaduste Akadeemia Uurali osakonna Udmurdi Ajaloo, Keele ja Kirjanduse Instituudi arhiiv, nimistu 2N, säilik 391.

\section{Kirjandus}

Bogajevski 1892 = Богаевский, П. М. Материалы для изучения народной словесности вотяков. Этнографическое обозрение 4.

Braginskaja 2000 = Брагинская, Нина В. Календарь. Токарев, Сергей А. (реаtoim). Мифы народов мира 1: $A-K$. 2. väljaanne. Москва: Большая Российская энциклопедия, lk 612-615.

Griškina \& Vladõkin 1982 = Гришкина, Маргарита В. \& Владыкин, Владимир Е. Письменные источники по истории удмуртов IX-XVII вв. Атаманов Михаил Г. et al. (toim). Материаль по этногенезу удлуртов. Ижевск: Науч.-исслед. ин-т при Совете Министров УАССР, lk 3-43.

Klimišin 1990 = Климишин, Иван А. Календарь и хронология. Москва: Наука.

Konakov 1996 = Конаков, Николай Дмитриевич. Традиционное мировоззрение народов коли: Окружаюший мир. Пространство и вреля. Сыктывкар: Коми научный центр, Институт языка, литературы и истории.

Kralina \& Pozdejev 1971 = Кралина, Надежда П. \& Поздеев, Петр К. (koost). Bamкa но Каллез: Удлурт калык легендаос но преданиос = Ватка и Калиез: Удиуртские народние лезенды и предания. Ижевск: Удмуртия.

Luppov 1931 = Луппов, Павел Н. Северные удмурты в XVI-XVII вв. На удлиртские тель: Сборник статей. Ученые записки НИИ народов Советского Востока 2. Москва: Центриздат., lk 112-144.

Lvova \& Oktjabrskaja \& Sagalajev \& Usmanova (koost \& toim) 1988 = Львова, Элеонора С. \& Октябрьская, Ирина В. \& Сагалаев, Андрей М. \& Усманова, Марьям С. 
Jelena Popova

Традииионное мировоззрение тюрков Южной Сибири: Пространство и вреля. Вещници мир. Новосибирск: Наука.

Meletinski 2000 = Мелетинский, Елеазар М. Время мифическое. Токарев, Сергей А. (peatoim). Мифи народов иира 1: A-K. 2. väljaanne. Москва: Большая Российская энциклопедия, lk 252-253.

Minnijahmetova 2000 = Миннияхметова, Татьяна Г. Календарные обряды закалских удлуртов. Ижевск: Изд-во Удм. ин-та истории, языка и лит.

Moškov 1900 = Мошков, Валентин А. Миросозерцание наших восточных инородщев: вотяков, черемисов и мордвы. Жиъая Старина 10: 1-2, lk 194-212.

Pervuhhin 1888 = Первухин, Николай Г. (koost). Эскизы преданий и быта инородиев Глазовского уезда 1: Древняя религия вотяков по её следал в совреленных преданиях. Вятка: Изд. Губерн. Стат. Ком.

Pervuhhin 1889 = Первухин, Николай Г. (koost). Эскизь преданий и бътта инородиеб Глазовского уезда 4: Следы язической древности в образиах устной народной поэзии вотяков. Вятка: Изд. Губерн. Стат. Ком.

Petrova 1937 = Петрова, Татьяна И. Времяисчисление у тунгусо-маньчжурских народностей. Мешчанинов, Иван И. (koost). Паляти Владилира Герлановича Богороза (1865-1936): Сборник статей. Москва \& Ленинград: Академия наук СССР, lk 79-121.

Popova 1997 = Попова, Елена В. Бесермяне (краткий историографический обзор). Шкляев, Георгий K. (koost \& toim). О бесерлянах: Сборник статей. Ижевск: Удмуртский институт истории, языка и литературы Уральского отделения Российской академии наук, $1 \mathrm{k}$ 3-18.

Popova 1998 = Попова, Елена В. Селейные обычаи и обряды бесерлян: (Конеи ХІХ90 -е XX 66.). Ижевск: Удмуртский институт истории, языка и литературы Уральского отделения Российской академии наук.

Popova 2004 = Попова, Елена В. Календарные обряды бесерлян. Ижевск: Удмуртский институт истории, языка и литературы Уральского отделения Российской академии наук.

Popova \& Tšernõhh 2003 = Попова, Елена В. \& Черных, Александр В. Представления о природных явлениях в мировоззрении куединских удмуртов. Журавлев, Виталий А. (toim). Этнос - Культура - Человек: Материаль международной науцной конферениии: К 60-летию доктора исторических наук профессора B. Е. Владыкина. Ижевск: Издательство АНК, $1 \mathrm{k}$ 281-288.

Potanin 1884 = Потанин, Григорий Н. У вотяков Елабужского уезда. Изъестия Общества. археологии, истории и этнографии при Казанскол университете III. Казань, lk 189-255.

Sokolova 1990 = Соколова, Зоя П. Времяисчиление у обских угров. Гурвич, Илья С. \& Соколова, Зоя П. Традииионная обрядность и мировоззрение иальхх народов Севера. Москва: ИЭА РАН, lk 74-103.

Svjatski 1966 = Святский, Даниил О. Очерки истории астрономии в Древней Руси II. Историко-лстронолические исследования VIII. Москва: Наука, lk 11-124. 
Škljajev 1997a = Шкляев, Георгий К. Краткая социально-демографическая характеристика бесермян. Шкляев, Георгий К. О бесерлянах: Сборник статей. Ижевск: Удмуртский институт истории, языка и литературы Уральского отделения Российской академии наук, lk 101-109.

Škljajev 1997b = Шкляев, Георгий К. Бесермяне: Опыт этностатистического обследования. Шкляев, Георгий К. О бесериянах: Сборник статей. Ижевск: Удмуртский институт истории, языка и литературы Уральского отделения Российской академии наук, lk 110-120.

Zlatkovskaja 1983 = Златковская, Татьяна Д. Исторические корни Европейского календаря. Токарев, Сергей А. (toim). Календарные об̆ции и обряды $b$ странах зарубежной Европь: Исторические корни и развитие обыцаев: Сборник статей. Москва: Наука, lk 24-39.

Zorin 1981 = Зорин, Николай В. Русская свадьба В Среднел Поволжье. Казань: Казанский университет.

Žukovskaja 1986 = Жуковская, Наталия Л. Пространство и время в мировоззрении монголов. Жуковская, Наталия Л. (toim). Мифь, культь, обряды народов зарубежной Азии. Москва: Наука, lk 118-134.

Tepljašina 1970 = Тепляшина, Тамара И. Язык бесерлян. Москва: Наука.

Toidõbekova 1997 = Тойдыбекова, Лидия С. Марийская язическая вера и этническое сальсознание. Joensuu: Joensuun yliopisto, Karjalan tutkimuslaitos.

Tokarev 1983 = Токарев, Сергей А. (toim). Календарные обыцаи и обряды $b$ странах зарубежной Европь: Исторические корни и развитие об̆иаев: Сборникстатей. Москва: Наука.

Tolstaja 1987 = Толстая, Светлана М. К соотношению христианского и народногокалендаря у славян: Счет и оценка дней недели. Успенский, Борис А. (toim). Языки культуры и проблель перебодилости. Москва: Наука, lk 154-168.

Toporov $2000=$ Топоров, Владимир Н. Модель мира. Токарев, Сергей А. (реаtoim). Мифы народов лира 2: $K$-Я. 2. väljaanne. Москва: Большая Российская энциклопедия, lk 161-164.

Tšagin 1998 = Чагин, Георгий Н. Окружающий мир $b$ традииионно и мировоззрении русских крестьян Среднего Урала. Пермь: Пермский государственный университет.

Tšagin 2003 = Чагин, Георгий Н. Взгляд коми-пермяков на пространство и время. Журавлев, Виталий А. (toim). Этнос - Культура - Человек: Материаль международной науцной конферениии: К 60-летию доктора исторических наук профессора В. Е. Владыкина. Ижевск: Издательство АНК, lk 413-418.

Tšernõhh 1999 = Черных, Александр В. Этнокультурная история Южного Прикалья по материалал. традииионой календарной обрядности в коние ХІХ - начале XX века. Автореферат дис. канд. ист. наук. Ижевск: Удмурт. гос. ун-т.

Vereštšagin 1886 = Верещагин, Григорий Е. Вотяки Сосновского края. Записки Императорского Русского географического общества по отделению этнографии 14: 2. Сангт-Петербург. 
Jelena Popova

Vereštšagin 1889 = Верещагин, Григорий Е. Вотяки Сарапульского уезда Вятской zуб. Записки Императорского Русского географического общества по отделению этнографии 14: 3. Сангт-Петербург.

Vinokurova 1994 = Винокурова, Ирина Ю. Календарные обычаи, обряды и праздники вепсов (конеи XIX - начало XX в.). Сангт-Петербург: Наука.

Vladõkin 1994 = Владыкин, Владимир Е. Реливиозно-лифологическая картина мира удмуртов. Ижевск: Удмуртия.

Vladõkina 1998 = Владыкина, Татьяна Г. Удлуртский фольклор: Проблель жанровой зболюиии и систелатики. Ижевск: Удмуртский институт истории, языка и литературы Уральского отделения Российской академии наук.

\section{Summary}

\section{Time as a Category of Traditional Besermian Worldview}

Elena Popova

Key words: Besermian, chronology, feast days, folk calendar, narrative lore, nychthemeron, traditional holidays, week, year

The article gives an overview of the traditional chronology of Besermians, which is a constantly developing and transforming system subject to various internal and external influences. As a part of a culture's worldview, time determines the rhythm of nature, lore culture, economic activities, and cycles of human life. Each part of the day was given a name. Midnight and noon were considered dangerous and special times. Weekdays were seen as positive (easy) or negative (difficult). The positive or negative nature of the day may have influenced the outcome of the work undertaken. The yearly system was based on the change of seasons. The change of seasons had a significant influence on the entire economic life, which, in turn, determined the community life, including family and practical rituals. Until the adoption of mechanical clocks, time has been calculated with various means at people's disposal. Observing the movement of the sun and the moon has been important. The Besermians have merged several traditional feast days, the tradition of commemorating the dead and other festivities with the Orthodox church calendar. 